\title{
Talking with a Volcano: Native American Perspectives on the Eruption of Sunset Crater, Arizona
}

\author{
Richard Stoffle ${ }^{1, *}$ and Kathleen Van Vlack ${ }^{2}$ \\ 1 School of Anthropology, University of Arizona, Tucson, AZ 85721, USA \\ 2 Living Heritage Research Council, Cortez, CO 81321, USA; kvanvlac@email.arizona.edu \\ * Correspondence: rstoffle@arizona.edu; Tel.: +1-520-907-2330
}

check for updates

Citation: Stoffle, R.; Van Vlack, K. Talking with a Volcano: Native American Perspectives on the Eruption of Sunset Crater, Arizona Land 2022, 11, 196. https://doi.org/ 10.3390/land11020196

Academic Editors: Vic Semeniuk and Margaret Brocx

Received: 9 December 2021

Accepted: 23 January 2022

Published: 26 January 2022

Publisher's Note: MDPI stays neutral with regard to jurisdictional claims in published maps and institutional affiliations.

Copyright: (C) 2022 by the authors. Licensee MDPI, Basel, Switzerland. This article is an open access article distributed under the terms and conditions of the Creative Commons Attribution (CC BY) license (https:// creativecommons.org/licenses/by/ $4.0 /)$.

\begin{abstract}
A new volcano erupted in the eleventh century AD in the San Francisco volcanic field, which has as many as 80 old volcanoes and 600 eruption cones all centered around Flagstaff, Arizona. This volcanic landscape has been a cultural center for Native American spiritual activities for up to 23,000 years. During that time, they have come to perceive volcanoes as earth navels and thus places where the earth is reborn. For this reason, the emergence of an active volcano, called Sunset Crater, drew pilgrims and resulted in the construction of ceremonial and support communities surrounding a place called Wupatki. This paper is partially based on a 2004 study funded by the U.S. National Park Service, which produced 80 ethnographic interviews with representatives of six Native American ethnic groups composed of 12 tribes and pueblos. The analysis is informed by a total of 23 ethnographic studies of volcanoes conducted with Native Americans by the authors. In all studies, Native American participants conveyed that they have cultural connections with volcanoes that derive from their Creation-based knowledge of the Earth as being alive and volcanoes being its rebirth. Traditional cultural information is critical to park management and compliance with various laws, regulations, executive orders, and policies so that park managers can better address tribal requests for continued access, use, and interpretation of park natural resources. Native Americans involved in our NPS ethnographic studies agreed that it is not necessary for the NPS to accept as true what Native Americans believe, but it is essential to tell in park interpretative settings both stories side by side with equal accuracy.
\end{abstract}

Keywords: volcanoes; Native Americans; United States National Park Service; geoparks; pilgrimage; Wupatki; Sunset Crater

\section{Introduction}

This paper is based on a case analysis that contributes to a literature on national parks and traditional people [1,2]. It does this by situating this case with other ethnographic research cases to better explain and educate visitors to sites of geological significance (geoheritage) in parks. An early compilation of research entitled Resident Peoples and National Parks [2] identified key issues poised by parks when they are established to conserve charismatic topography and natural resources but not to conserve and interpret the native people who traditionally occupied these lands. The 26 cases from around the world included clear challenges in situations, such as the Havasupai People and Grand Canyon National Park, U.S.A. [3], the Sherpas and Mount Everest (Sagarmatha) National Park, Nepal [4], and the Aboriginal People and Cobourg and Kakadu National Parks, Australia [5]. Despite the elapsed decades, these and most of the other cases remain unresolved. So, the problems of nature-based parks and resident peoples are fundamental and persistent.

It is important to move beyond park establishment proclamations in order to reach a more holistic interpretation for the millions of tourists who annually visit and are provided educational materials by the U.S. NPS. The NPS educates more people about Native American culture and their heritage places than any other public institution, including 
schools, libraries, and museums. Native American people, therefore, want the NPS to tell their stories accurately. An estimated 331 million people visited U.S. national parks in 2017 [6]. Where appropriate and consistent with a park's mission, all visitors are presented with videos, museums, and interpretative signs along trails that talk about Native Americans.

Park is the term of reference used throughout this analysis, even though many of the cases involve U.S. national monuments. The concept of park is more universally understood than that of monuments. Native American and Indigenous are terms of reference for the participating tribes and pueblos. The term American Indian is properly used in the United States to indicate federally recognized cultural groups.

Considered, also, is the issue of cultural heritage as a human component of geoheritage $[7,8]$. The former is a management concept used in the U.S. NPS $[9,10]$ and elsewhere it is often discussed and guided by UNESCO [11-13]. Cultural heritage studies are often a foundation for geoheritage as a management approach and even the establishment of geoparks [14]. The concepts discussed above have a range of definitions and uses; however, for this paper, they have been defined to best reflect the methods, data, and analysis of this paper.

Finding a new cultural interpretation of parks has been difficult for park managers who generally feel a sense of responsibility to stay within the "mission of protecting and interpretating" the park, as this was defined by the U.S. government when the park was established. Expanding the mission to include other topics is a serious decision for the U.S. NPS, so finding, through formal consultation, a Native American cultural heritage backstory of a park with a volcano-centered mission and a geological backstory to an archaeology park are challenges.

President Obama used his executive power under the Antiquities Act of 1906 to create Bears Ears National Monument, Utah on December 28, 2016. His executive order in part defined the mission of the new monument in terms of its cultural importance to Native Americans. These criteria in the mission statement then led to new forms of federal and tribal co-management [8].

This analysis is centered on two adjacent NPS parks, one conserved as a volcano, i.e., Sunset Crater National Monument, and the other an archaeology park, i.e., the Wupatki National Monument (Figure 1). After a century of operating with(in) the specific establishment mandates provided by two U.S. presidents, a Native American field based ethnographic study was funded to satisfy legal requirement regarding government-to-government consultation between these NPS parks and culturally affiliated tribes. When tribal and pueblo representatives were brought to the two parks, they identified a fundamental establishment error, because they determined that the parks are culturally connected to each other and are functionally related and integral to a single traditional ceremonial landscape. They recommended that the parks be interpreted and managed together with a culturally more accurate definition as the Sunset-Wupatki Ceremonial Landscape. This analysis considers the implication of this tribal recommendation made about twenty years ago. 


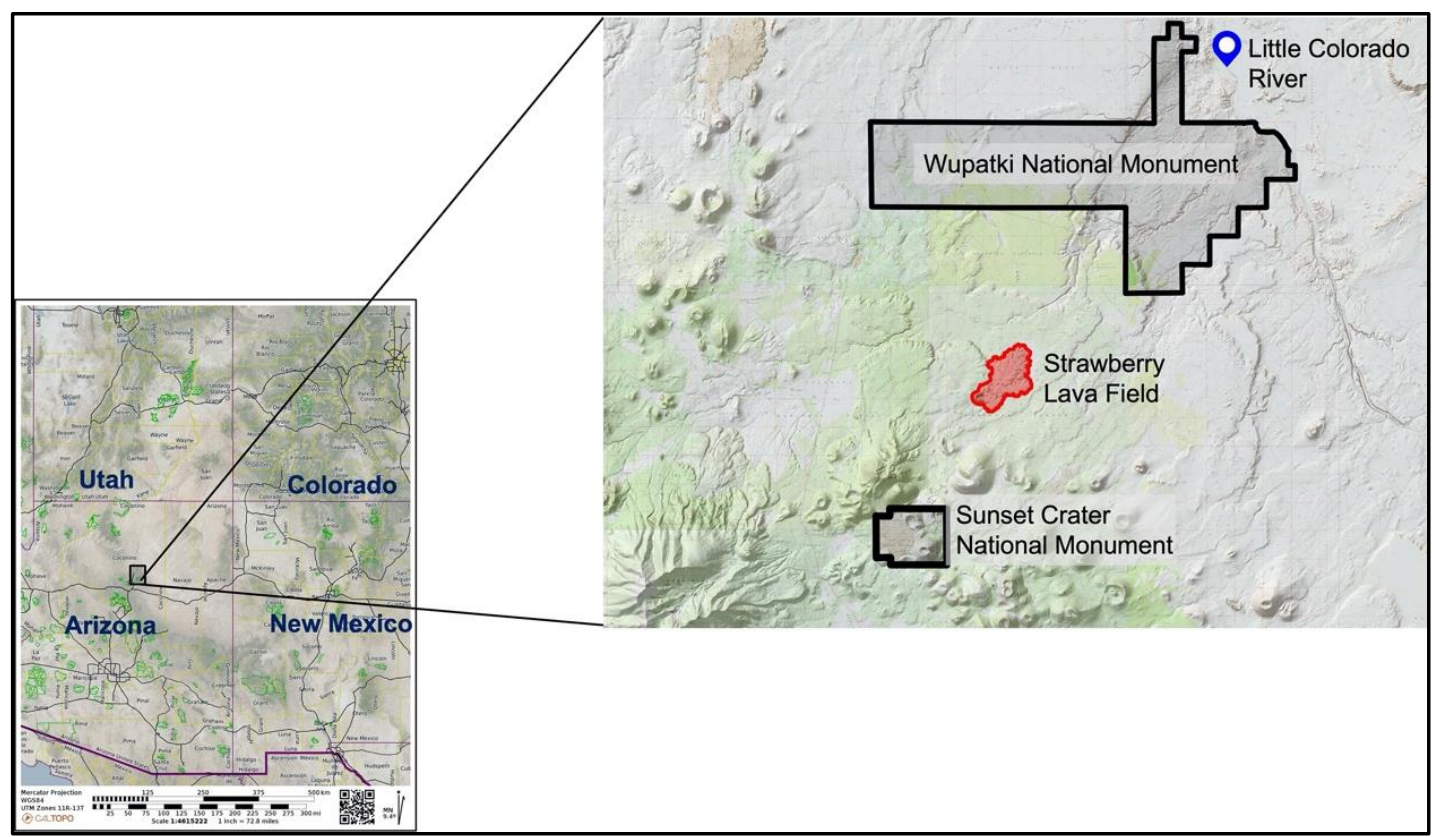

Figure 1. Wupatki and Sunset Crater Volcano National Monuments, north of Flagstaff, Arizona.

\section{Overview}

Anthropologists and geoscientists have studied the mutual relationship of traditional peoples and volcanoes [15-17]. Generally, it is one of respect and mutual understanding because the volcanoes are perceived as living Beings. Native American people residing in the western U.S. share an understanding of volcanoes as places where the earth is reborn and eruptions are the active process of rebirth $[15,18]$. They also share the epistemological understanding that the world is alive and thus sentient, having human-like senses and agency to accomplish its goals. At Creation, Indigenous peoples were given a birthright responsibility to listen to the Earth, including all of its living elements such as soil, water, wind, fauna, and flora and subsequently maintain a mutually respectful and beneficial relationship with these elements.

The location of our analysis is the San Francisco volcanic field (SFVF) which surrounds Flagstaff, Arizona (Figures 2 and 3). The SFVF contains approximately 80 volcanoes and 600 eruption cones [19]. At greater than 7000 feet $(2100 \mathrm{~m})$ elevation, the SFVF held glaciers in the Pleistocene [20]. The elevation of SFVF is important to the interpretation of its ceremonial uses by Native Americans.

The highest point in SFVF is the San Francisco Peak $(12,637 \mathrm{ft}, 3913 \mathrm{~m})$, which is a culturally central mountain for most of the Native American groups in the American Southwest [21-25]. The surrounding volcanoes have special individual meanings and are incorporated into a wide variety of traditional ceremonies [26]. The SFVF is part of various American Indian cultural landscapes that extend to home communities located on reservations hundreds of miles away. Pilgrimage trails connect the home communities to special destinations in the SFVF. These places are instrumental in world balancing ceremonies, healing ceremonies, and song and power acquisitions. The contemporary city of Flagstaff was a central location for intertribal events both sacred and secular. The SFVF is a volcanic landscape that has been a cultural center for Native American spiritual activities for up to the last 23,000 years [27]; so, in the late 11th century when a volcano became active in this already extensive volcanic landscape, Indigenous specialists came to the earth birthing event as pilgrims and formed or transformed a nearby village into a ceremonial support community. 


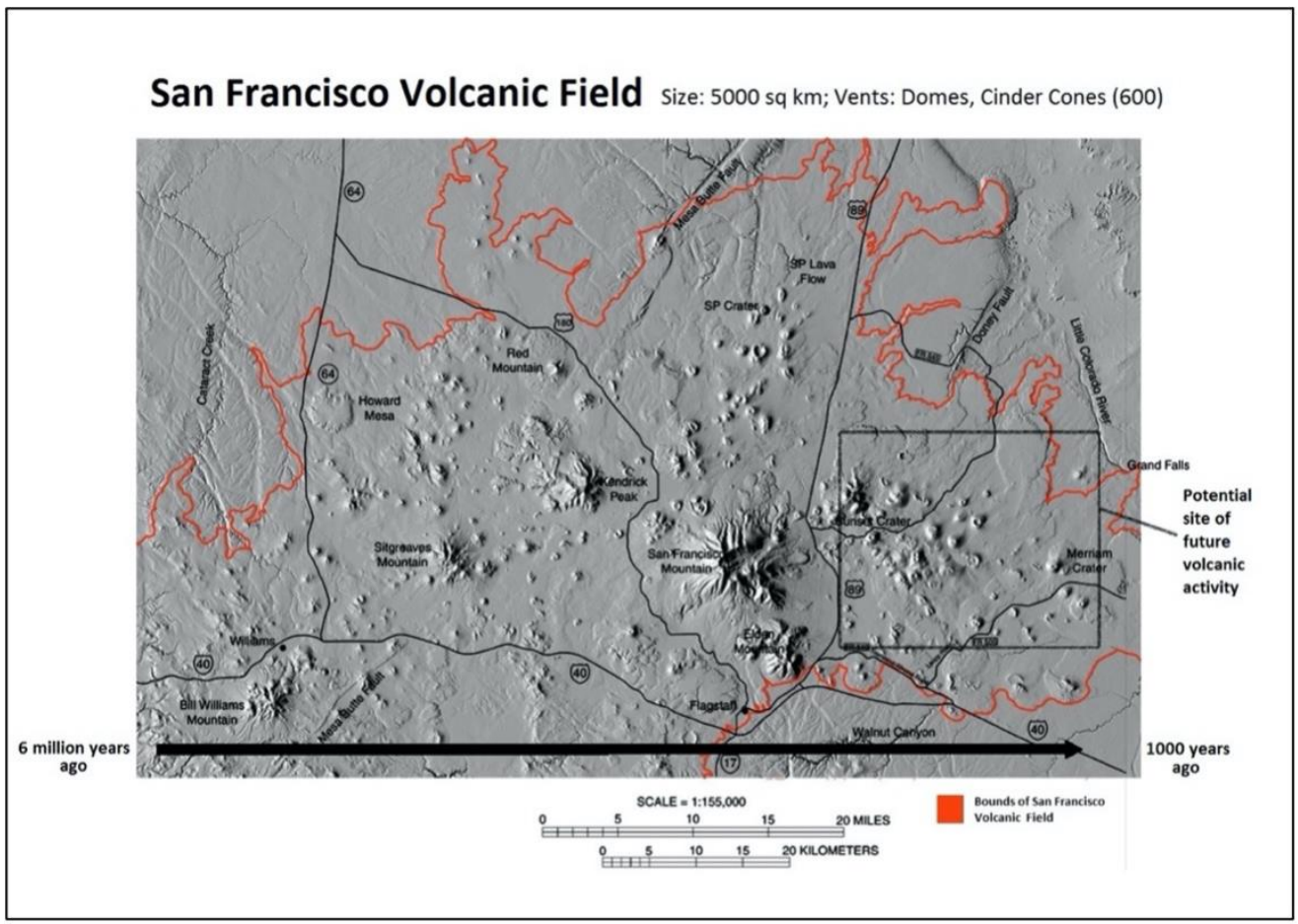

Figure 2. San Francisco volcanic field [28].

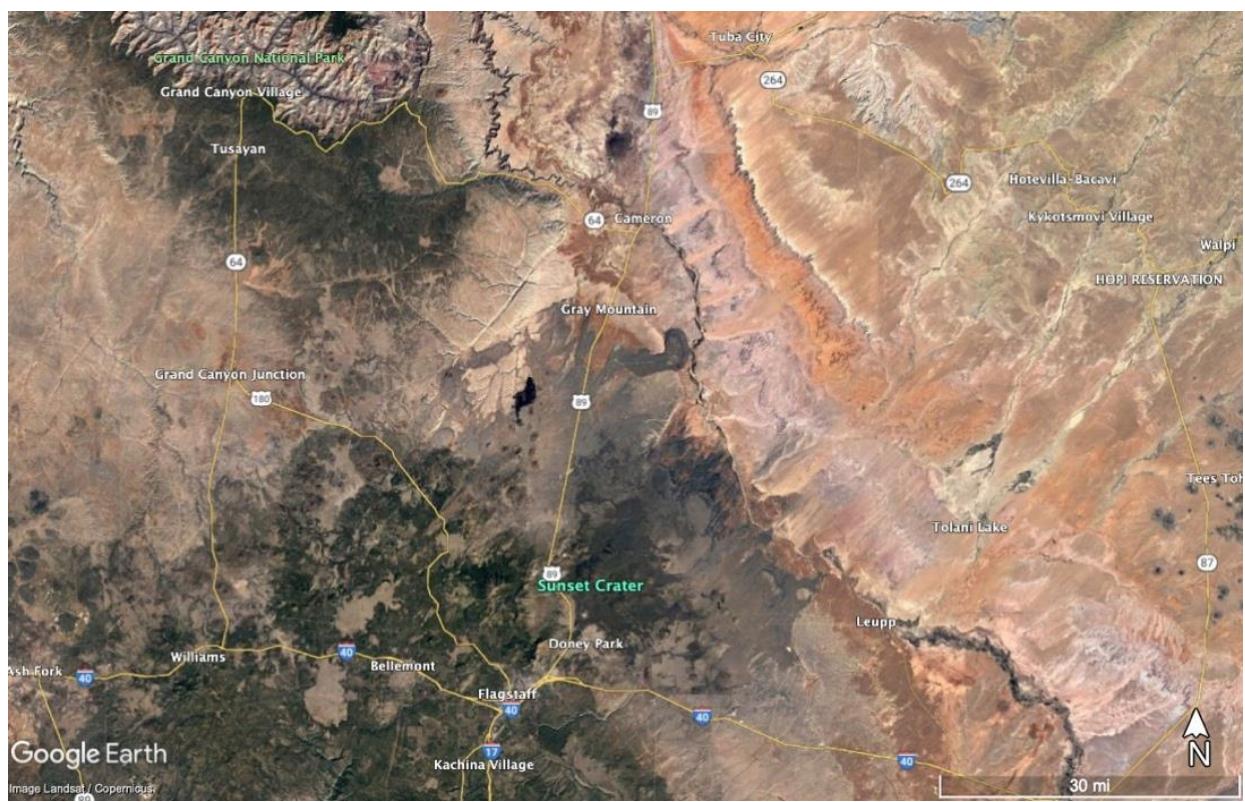

Figure 3. San Francisco Volcanic Field and Grand Canyon.

\subsection{The Eruption}

At $2451 \mathrm{~m}(8042 \mathrm{ft})$ in elevation, in a location surrounded by old volcanoes in the SFVF, a new volcano erupted producing a more than $340 \mathrm{~m}(1120 \mathrm{ft})$ high basaltic cinder cone and three large a'a style, or blocky, lava flows. The eruption issued from an 11-km-long fissure. The lava flows reached up to $11 \mathrm{~km}$ (nearly 7 miles) from the eruptive vent. It then became the youngest volcano in North America [29]. The eruption caused the relocation of an estimated 1000 Indigenous people from their homes and adversely impacted fauna and flora with a covering of tephra (clastic fragments ejected from the volcano) for about 


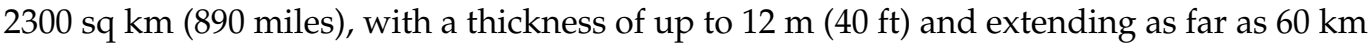
(37 $\mathrm{mi})$ to the southeast.

In the 20th century, the timing of this event become hotly debated by geologists, archaeologists, dendrochronologists, dendroecologists, dendrochemists, climatologists, paleomagnetic researchers, and biologists [18,19]. An accurately dated volcanic eruption would provide a timeline for many fields of study, so it was important to know when it erupted in the 11th century and hopefully to do so within the margin of decades. The debates also extended to the meaning of the eruption for Indigenous people.

\subsection{The Monuments}

The following section provides a short summary of how the monuments were established. This section also discussions the Native American involement in the interpretation of the parks.

\subsubsection{Establishment Legislation}

Wupatki (Figure 4) became a national monument with a proclamation by President Calvin Coolidge, naming it officially as an archaeology park on 9 December 1924, when he wrote:

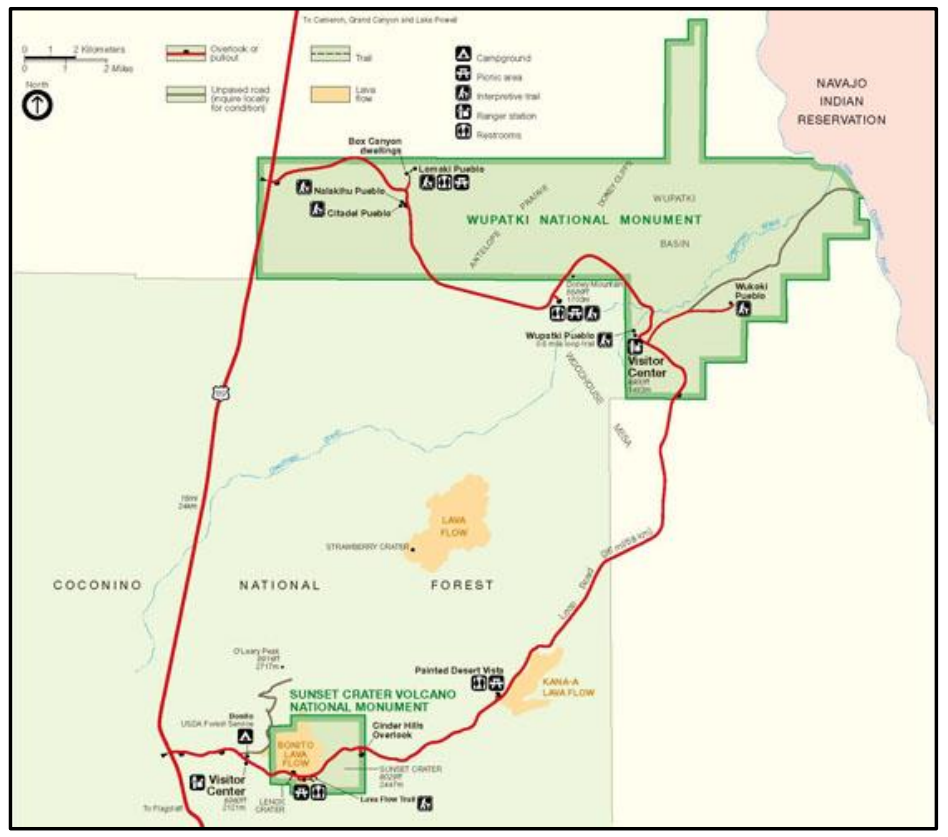

Figure 4. Official NPS Map of Wupatki and Sunset Crater Volcano National Monuments.

WHEREAS there are located in Arizona, about 30 miles northeast of Flagstaff, two groups of prehistoric ruins built by the ancestors of a most picturesque tribe of Indians still surviving in the United States, the Hopi or People of Peace.

Therefore, Wupatki the national monument was declared as only having two Hopi heritage ruins located in an archaeology park. This exclusive ethnic identification would become an issue of cultural affiliation later when such questions were required by federal law documentation.

Four years later, in 1928, a Hollywood Film crew sought permission to dynamite Sunset Crater for a film containing a landslide scene for the Zane Grey motion picture Avalanche. Scholars and the public were concerned and urged President Herbert Hoover to establish a new park, which became Sunset Crater Volcano National Monument, which he did in 1930.

After these two national monuments were proclaimed and thus officially given their missions, various kinds of scientists provided their professional assessment of what had 
happened and when it occurred at both the new volcano and the nearby archaeological communities. Government mission designations thus guided studies at Wupatki and Sunset Crater. At Wupatki, archaeological research dominated the discourse and interpretation, even though several volcanic lava tubes occur on the surface throughout the monument. At Sunset Crater, the monument focused on geological research and interpretation, despite the fact that there were corn rocks [30] (volcanic scoria with corn impressions) and extensive evidence of Native American ceremonial activity.

It is important to point out that little was known of these monuments before they were established, so it was inevitable that their mission statements would be overly focused on some resources and not others.

Native American representatives participating in the 2004 Ethnographic Overview and Assessment study chose to discuss key aspects of the parks according to their cultural understandings of the parks and the broader ceremonial area where the parks are located. The issues chosen by representatives both expanded and contradicted the establishment missions of the two parks.

\subsubsection{Sunset Crater}

Sunset Crater (Figure 5) was always a park with recognized nationally significant features and values, as these were defined by NPS designation criteria for sites of geological significance. The Sunset Crater Volcano National Monument was established in 1930. It occupies an area of $13 \mathrm{sq} \mathrm{km}$ (five sq mi) within Coconino National Forest. Arguably, it is a geopark.

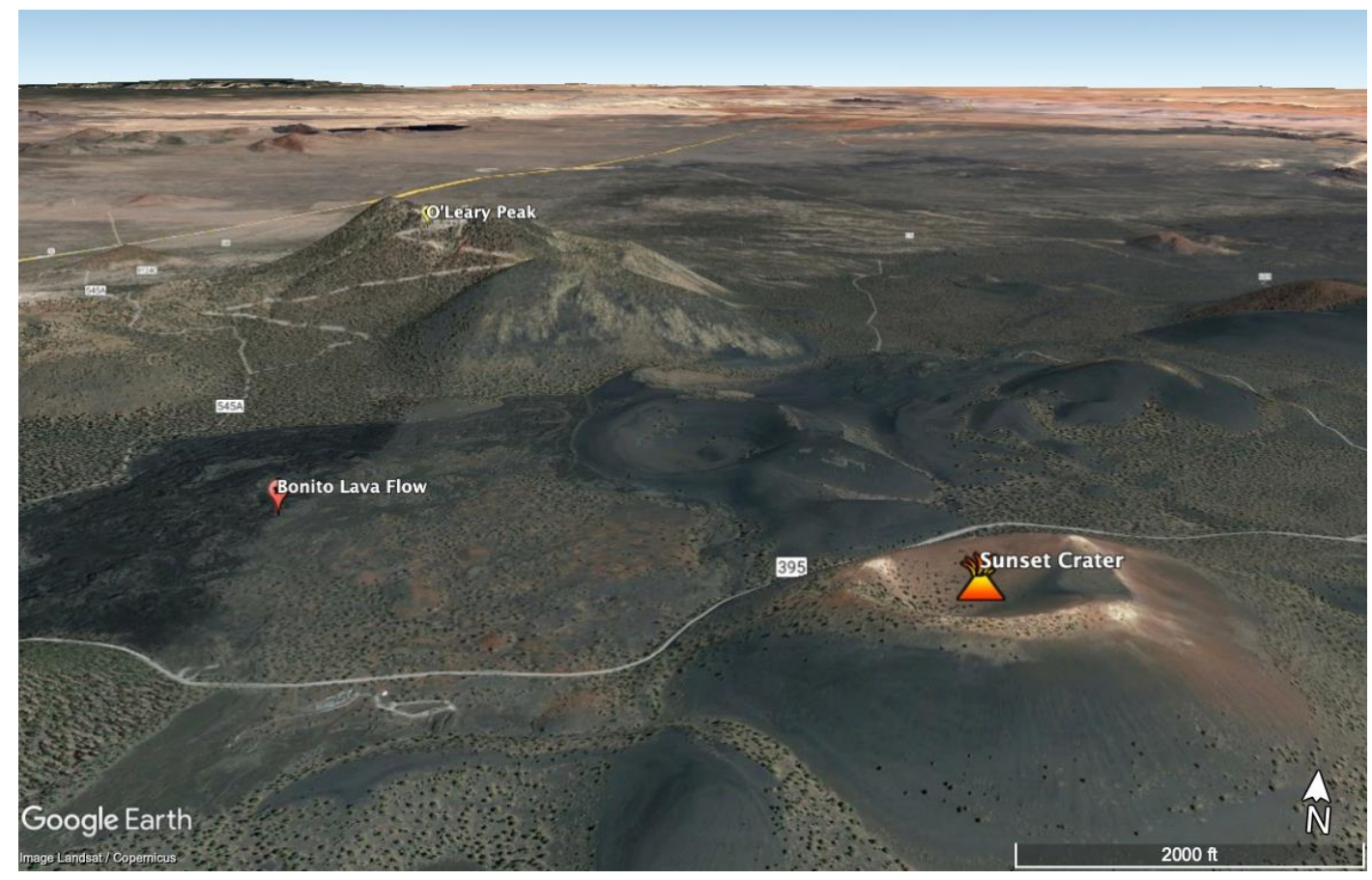

Figure 5. Sunset Crater and the San Francisco Volcanic Field.

Early in the history of Sunset Crater there was evidence that many Native American homes or structures had been covered by the eruption of ash and lava. Therefore, the park developed a theory based on archaeological interpretation that the eruption scared the resident Native Americans who ran away. This was illustrated in a painting that was prominently displayed for decades in the park visitor center of Indians running away from the eruption with their arms in the air in what was full panic. This theory and image lasted for generations and was the only Native American story told by the park, which would fund dozens of geostudies about the eruption. 
As the archaeology of the general area became more fully understood, it was apparent to the park managers that after the eruption and the removal of the Indigenous peoples, many returned despite a thick cover of tephra across much of the landscape. This problem was resolved by a theory that they returned because they were primarily farmers, and the tephra field better held the limited moisture normally available at this high elevation. The tephra made dry farming a more viable prospect than it had been before the eruption $[21,29,31,32]$. This theory is still considered plausible.

The discovery of corn rocks (volcanic scoria with corn impressions) in the walls of some structures, however, opened a new theory that stated Native American occupation of the two parks was ceremonial, as was in keeping with their response to the eruption of the Sunset Crater Volcano. Archaeologist Dr. Mark Elson was contracted to excavate some ruins that would be damaged by the widening of a road. His archaeological crew had members of the Hopi tribe who were experienced, if not credentialed, in archaeological excavation. During the excavation, 55 pieces of lava with 110 impressions of prehistoric corn (Figure 6) were recovered [33]. The Hopi workers offered an answer to the questions about how this happened and why the corn impressed rocks (corn rocks) were taken away from the lava flow and placed in the walls of structures. They maintained that ceremonial interactions occurred with the lava flow at the time it was hot with bubbling hornitos. The Hopi interpretation was seriously considered by Elson, but his colleagues who specialized in Southwestern archaeology were not convinced. Thus, Elson and Wendel Duffield PhD, a vulcanologist, went to active lava flows associated with Kilauea Volcano in Hawai'i to test various theories that would explain how this occurred. They agreed based on field experiments that the fresh corn was placed on the rim of an active hornito, and when a magma splash landed on the corn, a person would knock it off the rim, producing a separate corn rock or boulder. These corn rocks were then moved to a place where ceremony occurred.

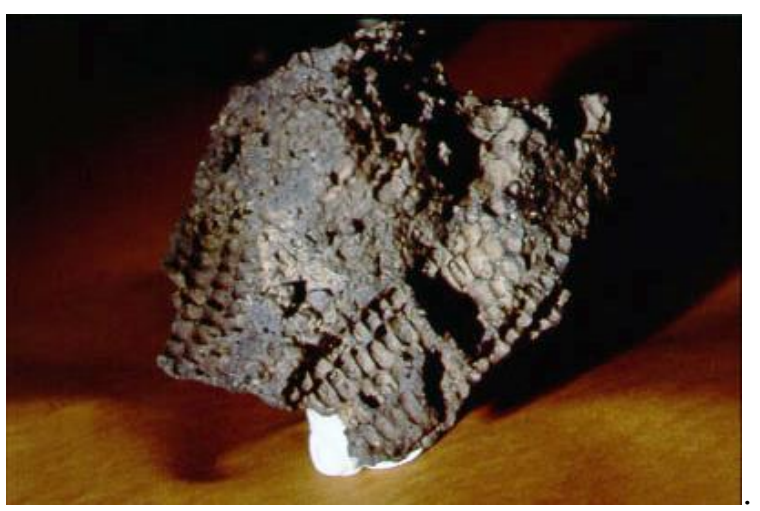

Figure 6. Corn impressions found in lava boulder during Elson's excavations [33].

An intellectual gap occurred between what was formerly believed and now identified: (1) the volcano was a fearful threat that sent local residents farmers running in fear and (2) spiritual leaders walked onto the lava flows to reach active hornitos in order to meld fresh corn and magma into stones for use in the building of ceremonial structures. The parks, however, largely did not (perhaps could not) address this intellectual gap. They did, however, remove the painting of the fearful Natives running from the volcano, replacing it with colorful paintings by various Native artists of people and volcanoes. Elson and his co-authors [34] concluded that the volcano would have been a spiritual event and that "... data indicate that most groups residing near an active (and often inactive) volcano incorporate such features into their belief systems, and volcano offerings are common aspects of associated rituals". 


\subsubsection{Wupatki}

Wupatki also received NPS research funding, but mostly for archaeological studies in keeping with its establishment mission. These studies identified six pueblos (that is, ancient communities of stone that are no longer occupied) in the monument, including Wupatki Pueblo (Figure 7), which is discussed here. Some structures were built before the Sunset eruption; however, after a brief hiatus, the area experienced great growth in both the number of structures and their complexity.

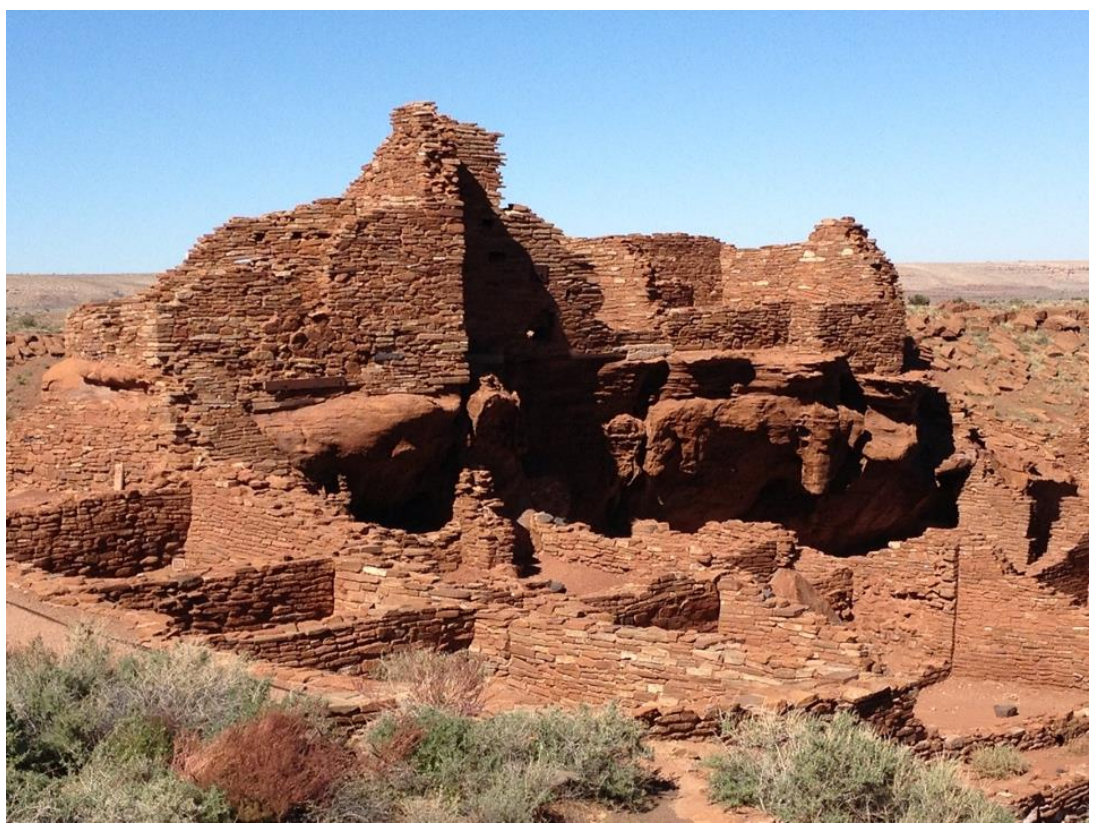

Figure 7. Wupatki Pueblo built on and around massive rocks [35].

Archaeologists and soil ecologists still posit a theory, discussed briefly above, that the tephra on top of the previous soil made it more productive for dry land agriculture, and that is why people moved back to the area after the volcanic eruption. That theory was challenged by tribal representatives, who argued from their oral accounts that the area was always sacred and that feature of the landscape attracted pilgrims from great distances. This sacred area became even more attractive after the Sunset eruption.

The archaeological park failed to fully consider the possibility that the volcano and the location where it occurred caused the sudden rise in population. Ironically, a Rand Corporation geoarchaeology study of the blowholes in Wupatki, conducted in 1962, supports this alternative theory [36]. The multiple blowholes in the Wupatki area apparently are related to the Sunset Volcano and as such have become a feature of the cultural landscape. During the day and night, air moves in and out of these holes or crevices. The Schley's study analyzed archaeological structures near blowholes and found most were initially constructed in the early AD 1200s, making them post-eruptive.

The report concludes [36]:

These geological curiosities were of some unique significance because their proximity to post-eruptive sites exceeds random change. The accepted hypothesis states that people settled in and around Wupatki because water was available and because the land had been made arable by volcanic cinders from the eruption. But even if this is true, the people' choice of specific sites within the area may have been due to more subtle influences. In historic pueblo culture ... physical needs appear no more vital to individual and community life than do metaphysical ones. Hopi metaphysical beliefs suggests that the air-breathing crevices may well have played a major role in the locating of some posteruptive sites. Crevices are known to have existed near all major ruins. With the possible 
exception of the Citadel ruin, available water is thought to have been considerably farther from these sites than were the crevices.

Of special interest for our analysis, many pueblo structures were built on and around massive stones (Figure 7), as well as near volcanic blowholes. The walls of most structures also contained a few volcanic boulders. Finally, the Wupatki pueblos were built just six miles from and 1000 feet higher in elevation than the Little Colorado River, the second largest in the region after the Colorado River (Figure 8).

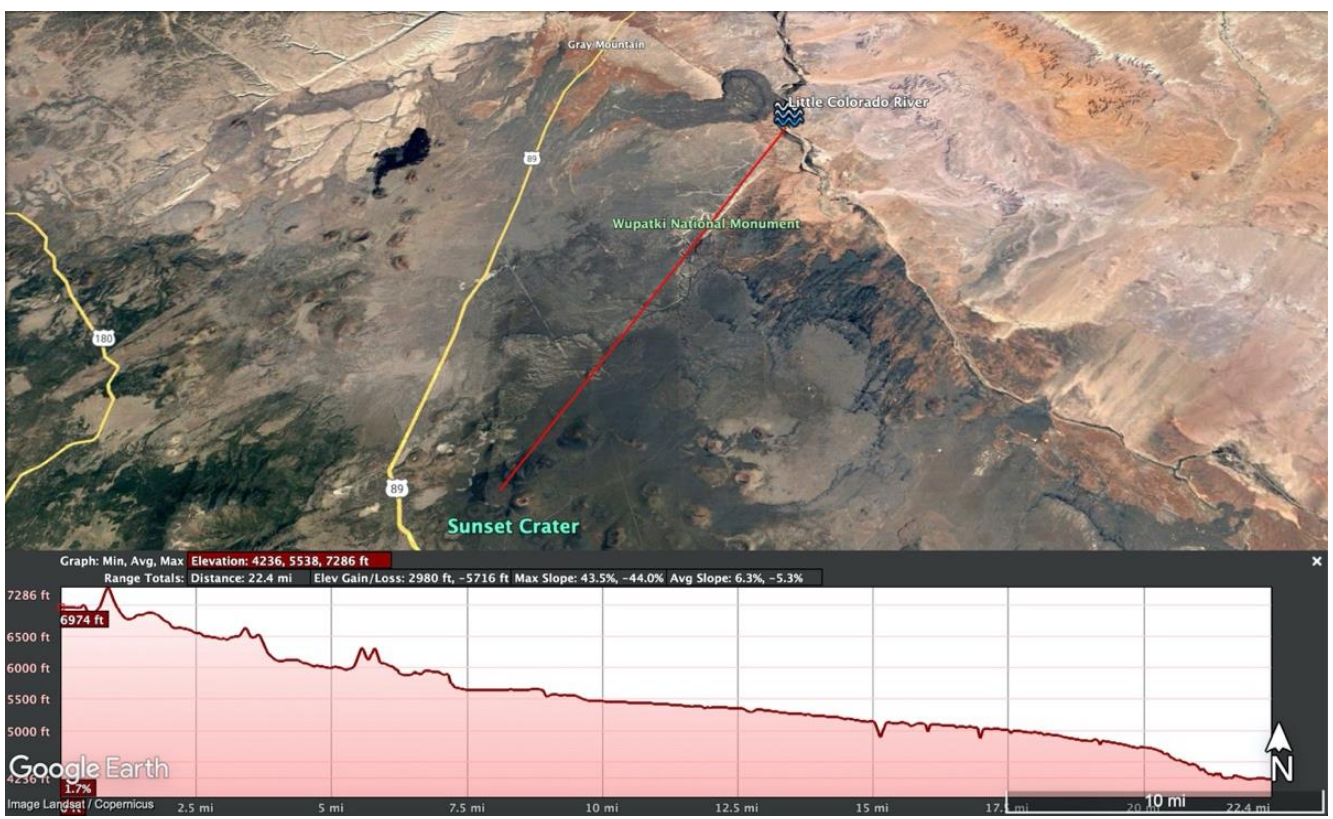

Figure 8. Elevation profile of Sunset Crater and Wupatki.

Native irrigated agricultural communities were located along the Little Colorado River at the time of the eruption as they had been for thousands of years. Why would large residential communities be established a thousand feet higher than the river in an area where dry land farming primarily would be forced to rely on rainfall? Why build farming homes on top of massive stones when miles of flat riverbanks were available? These questions were raised by the Native American representatives during the study.

\subsubsection{The Native American Voice}

The Native American voice officially became a part of the Sunset -Wupatki debate in 2001 and 2004. While certainly there were conversations between tribes and the parks before this time, these were informal and often did not leave a written record, which would only become official after review and approval by both NPS and tribal leadership. The Ethnographic Overview and Assessment is the contemporary term of reference for a formal government-to-government study. Our research studies in 2001 and 2004 reflected the early years of its methodological development.

\section{Methods}

Data used in this Sunset-Wupatki analysis were primarily collected in two ethnographic and ethnohistorical studies funded by the NPS. These two studies and the field methodology used for the second study are discussed below. These two studies are part of 23 ethnographic projects related to volcanoes, conducted by our research team with these same and culturally similar tribes and pueblos with the purpose of understanding Native American relationships with volcanoes. Those 23 projects are listed in Table A1 in Appendix A. 
All 23 ethnographic research projects involved one or more volcanic areas. Three studies focused exclusively on a specific volcano [37-39], one focused on ice caves produced by volcano lava tubes [39], and one focused on a basalt capped mesa covered by a massive lava flow and subsequent emerging cinder cones [40]. Other studies involved a variety of cultural resources such as fauna, flora, archaeology, special topographic features, hydrological systems, and, of course, volcanoes. Because the same tribes that were involved in the Sunset-Wupatki analysis had participated in multiple volcanic resource projects, the cultural interpretations in this analysis are increasingly detailed, better understood, and have a higher confidence level. Anthropologists call comparative analysis by the term Ethnology [41,42], and that 100-year-old comparative methodology is used here.

\subsection{Background to the Sunset-Wupatki Studies}

For the purpose of addressing their consultation responsibilities under the Native American Graves Protection and Repatriation Act (NAGPRA), the NPS contracted with the Bureau of Applied Research in Anthropology (BARA) at the University of Arizona (UofA) to conduct a document-based cultural affiliation study of four national monuments in northern Arizona: (1) Navajo National Monument, (2) Sunset Crater Volcano, (3) Walnut Canyon, and (4) Wupatki.

The first study [43], which reviewed documents in the National Park Service's Flagstaff and Regional Offices, revealed a need for ethnographic field data about the traditional uses of natural resources by six ethnic groups: the Pai, Southern Paiute, Hopi, Zuni, Navajo, and Western Apache.

BARA contracted with the NPS to amend and expand the cultural affiliation document using primary field data from representatives of the tribes that were found to be historically and culturally affiliated with Sunset Crater Volcano, Walnut Canyon, and Wupatki National Monument [44]. Additionally, the addendum to the affiliation study included information about traditional uses of park resources as described by tribal representatives. Ethnobotany and cultural landscapes associated with each park were major additions to the traditional use portion of the study.

Traditional use information is critical to park management and compliance with various laws, regulations, executive orders, and policies so that park managers can better address tribal requests for continued access, use, and interpretation of park resources. The two studies provided an understanding of broader Native American cultural landscapes, trails, the cultural meanings of the San Francisco volcanic field, and the many interconnected places that had been established as people used this area for secular and sacred gatherings over the past 23,000 years. Three travel corridors were documented by the studies as coming together in the Flagstaff area, thus reflecting ancient intertribal relationships.

\subsection{Data Gathering Methods}

The 2004 Traditional Use Study was based on interviews with elders and representatives who were selected by their tribal governments to participate in field visits. The Hualapai Tribe, Hopi Tribe, and Navajo Nation were unable to participate in the study; however, each was given the opportunity to provide written material pertinent to the traditional uses of the three parks. These written responses were incorporated in the appropriate ethnic group sections for each park and landscape.

During four three-day study periods that were spread over two years, our assessment teams visited each park with representatives from one of the Pai, Southern Paiute, and Apache ethnic groups, each of which included multiple tribes. In the spring of 2001, our team met with representatives from the Pai and Southern Paiute groups, and in the spring of 2003, we met with representatives from the Zuni Pueblo and Western Apache groups. The Hualapai tribe was unable to arrange transportation for elders to participate in the study; however, they did submit written material pertinent to the study and provided sitespecific and landscape data by telephone. The majority of their contribution was concerned with ethnobotanical, spiritual, and legendary use of the three parks and resources. The 
Hopi and Navajo tribes were unable to participate in field visits but contributed written materials to the report.

The research team spent an average of one day at each park, beginning with Wupatki and ending with Walnut Canyon. After visiting specific places, quiet locations were found where private interviews could take place. At Wupatki, the Wukoki and/or Wupatki sites were discussed at Doney Mountain, while the Citadel and Lomaki site discussions occurred at those locations. At Sunset Crater, the volcano was discussed as a site at the Lava Flow Nature Trail, O'Leary Peak and the Visitor Center. Walnut Canyon was treated in its entirety as a single site, and discussions took place along the Island Trail wherever representatives found an enjoyable setting. Discussions were held along the Rim Trail with those participants who were unable to take the Island Trail. The Walnut Canyon discussions were the most difficult in terms of visitor interruptions. Our preceding work with tribal representatives at the other two parks, however, had created a comfortable environment for the representatives with our team, so the interruptions had little effect. The landscape and map discussions took place at either Lomaki or Sunset Crater.

A total of 80 field interviews were conducted. These included 76 formal interviews and four informal on-site interviews. Pai representatives were from the Havasupai and Yavapai Apache tribes (the latter is an ethnically composite tribe); Paiute representatives were from the Kaibab Tribe and San Juan Tribe; Zuni representatives were from that pueblo; Apache representatives were from San Carlos, White Mountain, Yavapai-Apache, and Camp Verde Tribes. Each representative was interviewed by a professionally trained ethnographer from the UofA who had formal training and field experience in at least two other ethnographic projects involving Native Americans.

\section{Findings}

The following is a summary of findings from the Native Americans in field consultations at Sunset Crater and Wupatki in 2004 [44]. The findings represent an important, but small, subset of information shared by tribal representatives during that study. For a full understanding of ethnographic findings, the full study should be consulted.

\subsection{Sunset Crater National Monument}

Predominant features identified and interpreted by the park include Sunset Crater, the Bonito Lava Flow, the Cinder Hills, Lenox Crater, hornitos, squeezeups, lava tubes, and an ice cave in a lava tube [45]. These features are noted in Figure 9. Trails for visitors have been developed at most of these locations.

The detailed ethnographic data for the Pai, Southern Paiute, Zuni, and Western Apache groups is summarized to present a more concise report of each group's relationship with Sunset Crater and Wupakti. Although the Hopi Tribe and Navajo Nation were unable to participate in the study, they provided us with documents about traditional use of the Flagstaff area, from which we have compiled summaries of their relationships with the Sunset-Wupatki area.

Situated within a multi-cultural use area, Sunset Crater Volcano National Monument is important in many ways to the Native groups of this study. Plants, geologic features, and places comprise the resources of greatest concern. All the participating tribal representatives, including the Hopi Tribe [46] and the Navajo Nation [47], stated a need to conduct a thorough inventory of plants in the park before they could make specific management recommendations with regard to the protection of flora and fauna, including access and use requests. They also emphasized uses of plants for food, medicine, and ceremony. The power or energy of plants growing near volcanoes is greater than the same plants growing elsewhere. This accounts more for the common mention of plants than whether or not they could be gathered at another location. 


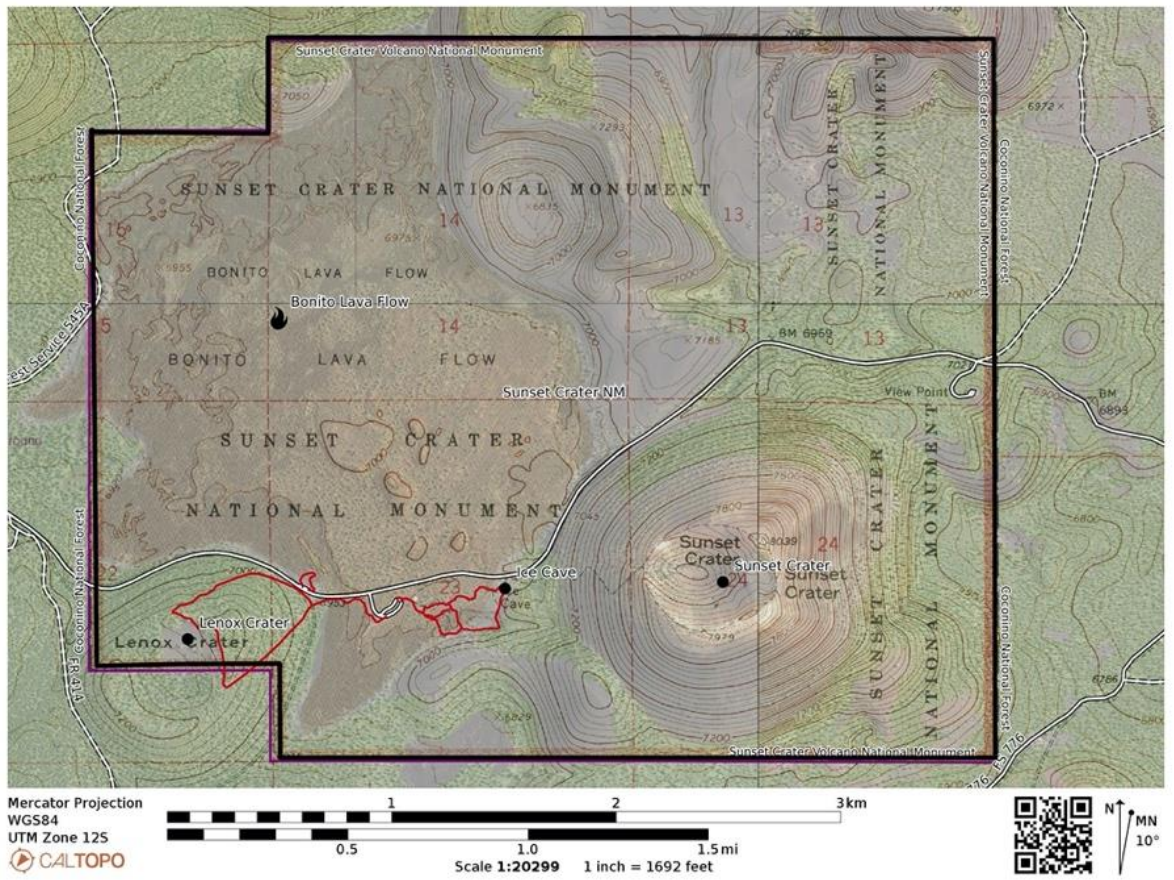

Figure 9. Map of Sunset Crater.

All Native groups identified the ice cave, lava rocks, and cinders as culturally significant. The Zuni Tribe also identified yellow and blue/green pigments and crystals. The Southern Paiute representatives included activities on top of volcanic mountains for vision questing and spiritual communication with other tribes. Sunset Crater, Bonito Park, the lava flow, and O'Leary Peak were identified by the six groups as having cultural significance. Although O'Leary Peak is not part of the park jurisdictionally, tribal representatives view it as part of the Sunset-Wupatki area under study.

Implicit in the discussions and information in Mercer [46] and Begay and Begay [47] is the idea of Sunset Crater as a place of power, spirituality, and respect. Unlike EuroAmerican associations of death and destruction with volcanoes, the Native groups recognize the volcanic activity of Sunset Crater as involving lessons of rebirth that are necessary for human survival. The drastic changes in the land that Euro-Americans see as destructive are viewed by Native Americans as indications of imbalance that the Creator is correcting. The presence of cinder cones, eruptions, and lava flow is seen as evidence that the mountains themselves are alive and have the power to act. These places are talked to and, consequently, treated with great respect [43]. This epistemological premise is compatible with the unifying geological theory of "plate tectonics" that describes the dynamic processes of mountain building, volcanism, earthquakes, landslides, tsunamis, creation of ocean basins, movements of continents, and all other dynamic process within the upper $3000 \mathrm{~km}$ of Earth.

\subsubsection{Southern Paiute}

The Southern Paiute name for Sunset Crater is Kaiv Pa'kectis, meaning "Mountain with hole or water bowl on top". This area has been used traditionally to collect basket-making materials, medicinal herbs, and food plants. The Paiute also hunted and fished in this area and recognize a strong connection between Sunset Crater and Wupatki. Evidence of previous Native American use of the area included Paiute baskets and bodies such as one found in one of the caves. Snow melt from the mountains and ice from the caves was used for subsistence and domestic purposes but also had medicinal and spiritual uses. Significant geological features include the volcano and the ice cave. The consultants speculated that the Native Americans who witnessed the volcanic eruption were frightened because it was such a powerful event. They returned to the area once the land had cooled. 
Both prehistorically after the event and today, these features are visited seasonally for seeking knowledge and power, to communicate with spiritual Beings, and to receive songs from the caves. It is recognized by geologists that wind blowing through lava tubes can have a song-like quality.

\subsubsection{Zuni}

Although a specific name for Sunset Crater was not offered, the Zuni people refer to the San Francisco Peaks and the surrounding area as Kwa ba chuwa llona. The Zuni people also have names for volcanoes and sharp volcanic rocks but given the sacred and powerful nature of these materials, they did not feel it appropriate to share that information at this time. As in the past, the Zuni people regularly visit the San Francisco Peaks to obtain spiritual power and to ask for blessings. Sunset Crater is believed to possess a similar capacity, as it is positioned near a point of pilgrimage. Resources in the park that the Zuni identified as significant to the landscape include scenery, valleys, plants, air, and Sunset Crater. Traditionally, people would have settled or camped in the park's vicinity but not near the crater. They would have come to hunt, gather herbs, and collect minerals and volcanic rocks. Ceremonies would have occurred in special places such as in the ice cave, to which Zuni people continue to make pilgrimages for offerings and other religious practices. They also engaged in star observations at various places in the park.

Many of the features in Sunset Crater are connected to distant places such as Zuni in New Mexico and north of the Colorado River at the Kaibab Paiute reservation. The unique geological features of Sunset Crater, for example, are essential to Zuni culture. From prehistoric times, items such as pigments, metal deposits in the lava, certain minerals, or crystals found near volcanic activity have been gathered as necessary: daily, seasonally, and annually in the Sunset Crater area. Lava rocks such as basalt have been used as grinding utensils. Sharp lava stones were used for scraping flesh off and softening animal hides. Yellow, red, and blue sands are employed as paint and in ceremonies. Today, cinders may be used in oven floors because of its heat retaining ability. In religious terms, the ice cave and Sunset Crater are referred to in Zuni migration songs. It is believed that the cave ice is pure and has healing properties. Offerings are left by Zuni people not just for the Zuni, but also for all the people in the greater region to ask for good health, rain, and productive crops. The volcanic area is used for (1) communicating with spiritual Beings, (2) seeking knowledge and power, and (3) teaching younger generations about the cultural significance of the place. These activities may be accomplished by performing ceremonies in the ice cave or in special geological places within the monument's boundaries. Finally, the San Francisco Peaks stand as a significant territorial marker defining this as a culturally central and jointly used area for all the tribes and pueblos in the region.

\subsubsection{Hopi}

Culturally significant geologic features and places within or adjacent to the park include lava rocks, the ice cave, or Patusungki, meaning home of the ice, O'Leary Peak, and Bonito Park. Lava rocks are used in ceremonies, and the Sunset Crater area is the Hopi people's nearest source of lava rock. The ice cave continues to be an important ceremonial place to where certain Hopi societies make pilgrimages and leave pahos, or prayer sticks. All of the Water Clans visit the ice cave for ceremonial purposes, and members of the Two-Horn Society collect ice from the cave for ceremonial use. O'Leary Peak is the eagle-collecting area of the Snow Clan, and Bonito Park is a traditional hunting area. As such, Bonito Park is a place of hunting rituals and songs. It is a plant-gathering area as well, but perhaps its greatest significance is as the ceremonial womb of the kachinas, who live in the San Francisco Peaks and who pass through Bonito Park on their annual journeys to the Hopi mesas [46].

\subsubsection{Apache}

The Western Apache have interacted with $K o^{\prime}$ ha godi'i' $h i^{\prime} i{ }^{\prime} k a^{\prime} a^{\prime}$, 'the burnt place,' for centuries. As one elder described it, Sunset Crater serves to remind the people of how the 
forces of good can prevail over evil. The crater and lava flows are all that remain of a battle that saved the Apache people long ago:

The fire, the burnt area and the fire is a reminder of the salvation of our people. And what it pertains to, and I won't go into all the details, but it needs to be known that Good and Evil, so to say, had a battle here. And Good won, because what had happened was that Evil had ... taken control of us men and so Good came in, and in the battle he won us back to what we are today. So Evil then burnt himself up and that's why it's a reminder of that. This place [made us] who we \are today because Good won. This is a holy place; the peaks are a holy place too (Apache consultant).

Although Evil lingers in the area, when the forces of Good triumphed, they left behind positive things that the Apaches continue to come here to use. After this event, Dzil'cho, the San Francisco Peaks, and the surrounding landscape including Sunset Crater, Mormon Lake, and Prescott were inhabited by Apaches. As one elder explained it, this notion, as well as other traditional understandings of Apache use of the area, often conflict with scientific conceptions of who they are and where they have been.

These sacred areas have been used for a variety of purposes, including hunting, gathering food, camping, praying, and performing ceremonies. The Apache people have stories that tell of them making pilgrimages to Sunset Crater to gather medicinal and food plants such as Apache plume and rabbitbrush.

\subsubsection{Navajo}

Navajo stories identify two significant places within Sunset Crater Volcano National Monument: Sunset Crater and Bonito Park, which the Navajo call Hootso, or the Meadow. In the first account, the creation of the crater is described. The second story describes the religious significance of Hootso [47]. This mountain, Dzit K'ídz'itsoi, was heated to boiling. It is said that the sun was responsible for this crater. The sun set fire to the mountain and to the land. It is said that at the time the land was small. From then on, however, the land grew and became as large as it is today, but the sun is responsible for Sunset Crater. This happened after the Grand Canyon was gouged out of the ground. The creation of the Grand Canyon is another story.

The peaks of Dook'o'ostiid are where the Yé'ii Bicheii come from. The Yé'ii come here and stop here before they go to the Navajos. There is a place similar to this at Dibé Ntsaa and the La Plata Mountains (in Colorado). There, the holy people leaders meet at this nice flat area, or meadow. These holy ones come from the [sacred] mountains, the gods.

\subsection{Wupatki National Monument}

Wupatki is composed of six pueblos: (1) Wupatki where the visitor center is located, (2) Wukoki near a major blowhole and has a very large walled enclosed dance or ball court area, (3) the Citadel on a mesa, (4) Nalakihu below the mesa, and (5) Lomaki and (6) Box Canyon are near one another just outside the park boundary (Figure 10).

Wukoki Pueblo is within view of Wupatki. Both are built around large stone outcroppings, but Wukoki also has a lava tube blowhole and a large ceremonial gathering or dance area (Figure 11).

The Wupatki area seems to have been heavily used by all the tribes in this multicultural use area. It continues to be extremely important in many ways to the six ethnic groups of this study. Plants and ceremonial places are the primary resources of native concern; however, wildlife, springs, ruins, and other signs of previous use are important as well. Traditional uses of the site centered on plant gathering and ceremonial activities, including spiritual experiences and teachings, hunting, and farming. 


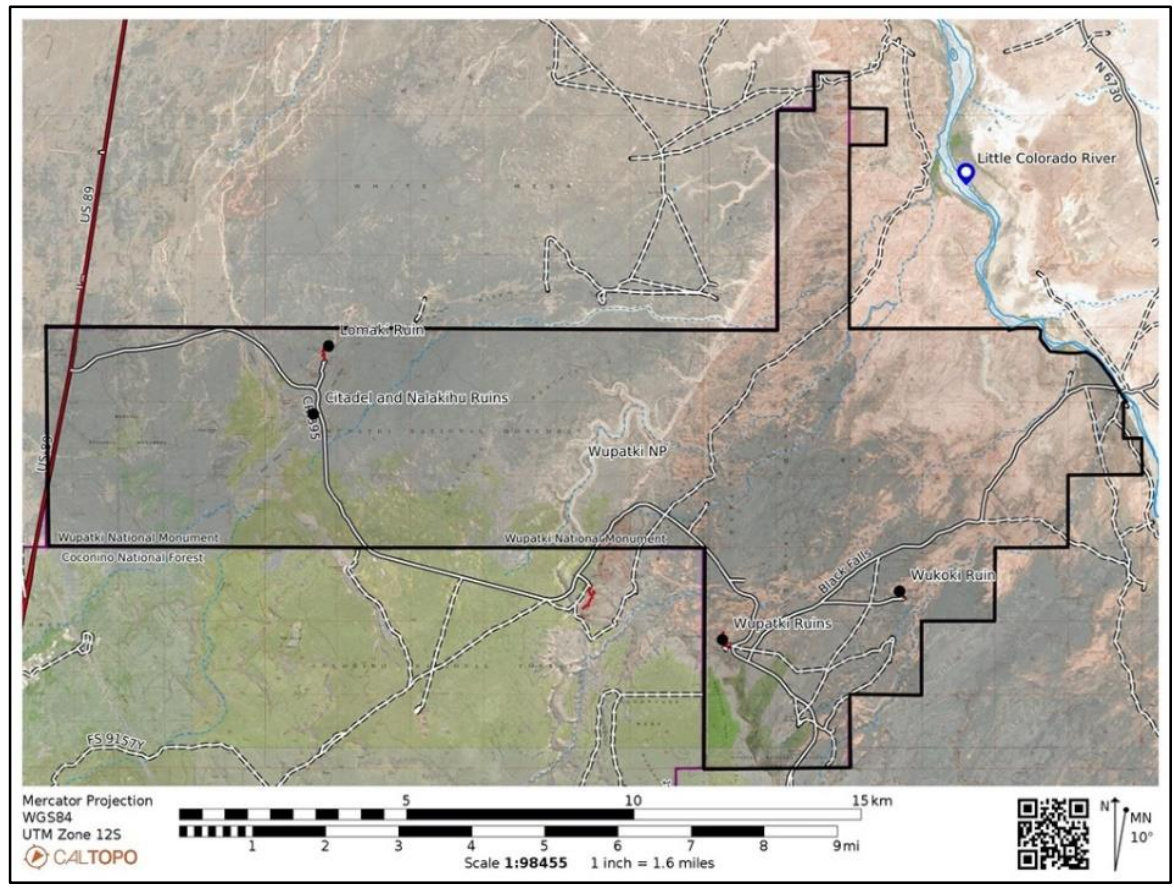

Figure 10. Map of Wupatki National Monument.

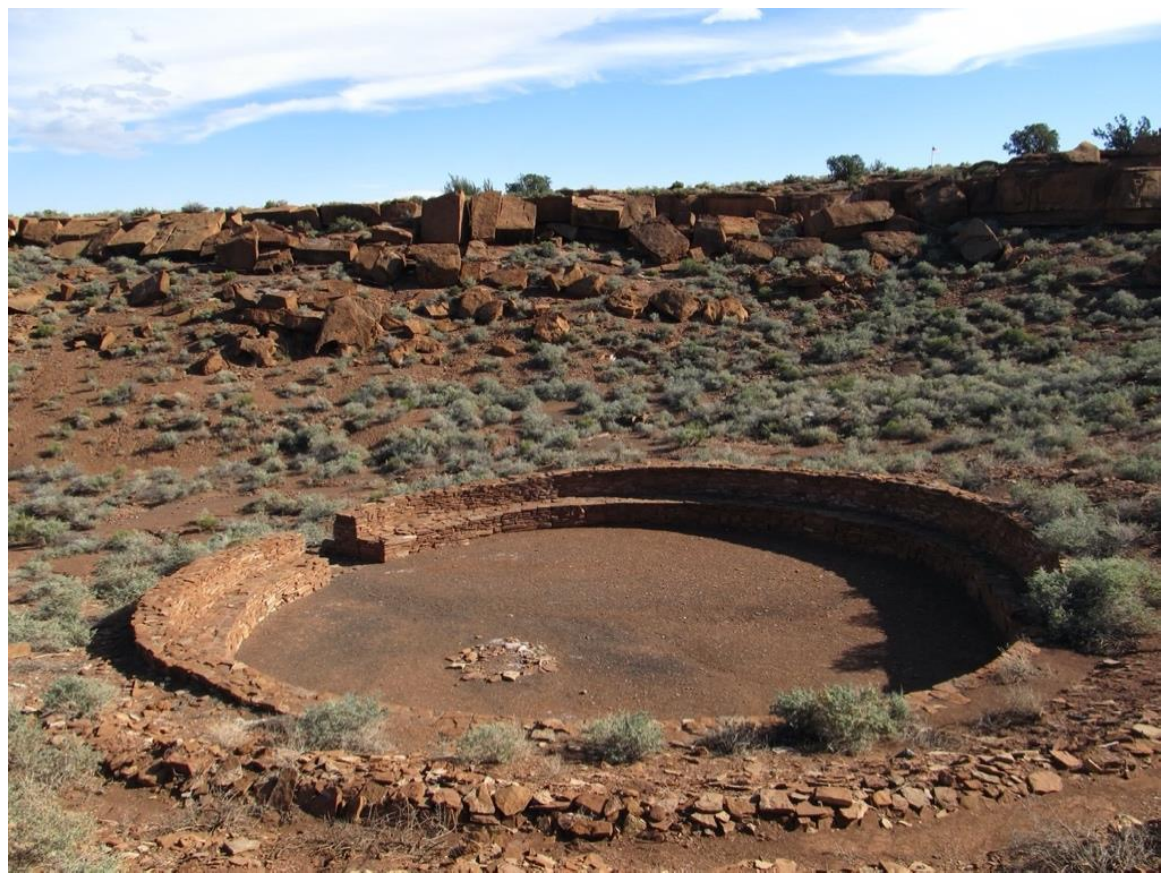

Figure 11. Ball court and ceremonial gathering area at Wupatki [48].

While the Native American representatives did not express the need to conduct a comprehensive plant inventory of the park, as they did at Sunset Crater, the many traditional use plants identified during the site visits in Wupatki suggest that a complete ethnobotany inventory should include both parks. The tribal representatives, Mercer [46] and Begay and Begay [47], emphasized that known park plants are used for food, medicinal, and ceremonial purposes. Plants that grow in these ceremonial areas are especially desired. 


\subsubsection{Pai}

The Pai elders said that the ball court and ruins at Wupatki were evidence of traditional use. The ball court or Gh-tsuo-o was identified as a place of games, trading, and meetings. The ruins, particularly at Wukoki, were identified as places of power. They used to play games that were similar to hockey with a ball (although it required a larger rectangular game area). At the ball court, there was also a meeting area. Wupatki was probably a trading place. It is in a central location. This place is between the Verde Valley and Hopi. Coconino is a Hopi word to describe Pai people.

At Wukoki, according to a Pai elder, you could feel the power. Something came out and touched me. There is more power there than at the main ruins. It was built strong. Geologic features of cultural importance include the blowhole and the round boulders with holes drilled through them at Wukoki. One representative explained connections between the two as deriving power from Wukoki for use at Wupatki:

It is a power point ... an area to gather medicine or power for their spirituality. Sma'buuga is a place to gather power, and Geegaga is a place to gather strength. Young shaman would come here and get power. Older shaman would come from their homes using their mental ability to pray. The wind can give you a song just like water can. The wind has a story spirit. Wind in the hole is strong and pure ... a powerful place.

One elder believed that geologic features were used for health, refreshment, cooling, and heating. Speaking about the blowhole, one elder stated, "Runners from Hopi and the Verde Valley refreshed themselves while on route. This would be a good place to do it." Another elder also said, "The round boulders with the rounded holes in them would be good places to make game sticks that were used for the ball court games. The sticks brought the power from Wukoki to help win the games played elsewhere."

\subsubsection{Southern Paiute}

Southern Paiute people refer to this area as Nuvaharka, a term that is applied to the entire San Francisco Peaks region. The elders noted many special characteristics about the Wupatki and Wukoki sites. In addition to living and playing games at Wupatki, the Paiute representatives believe that it was a trading place. The elders explained that the two places are sacred because of connections to many other places.

An elder said that this place is not too far from San Juan Southern Paiute aboriginal lands. When people crossed Lee's Ferry (where the water was low), they would go through San Juan to Wupatki. Going to the Grand Canyon, there was another crossing. There was open cave and a source for red paint next to the river. The water was low there, too. Paiute oral history and San Juan Paiute stories document that the whole area from SFVF was spiritually connected to ones near the Grand Canyon. This is a sacred region for Paiutes.

The Southern Paiute elders found similarities between the blowhole at Wupatki and those found on north of the Colorado River, such as the one near the town of Hurricane, Utah. They called the blowhole areas hurrikanni, house of the wind. They said that these are special areas where people would come and talk to the wind and the wind would talk to people.

\subsubsection{Zuni}

Wupatki National Monument is culturally connected with all Zuni ancestral sites in Arizona, Utah, New Mexico, and Colorado. Many of these places are united by their common architecture, which includes kivas and plazas, and are mentioned in the Zuni migration stories.

All the geological features in the two monuments have cultural significance for the Zuni people, who have names for each mountain in the region, including Doney Mountain and the San Francisco Peaks. These landforms as well as ice caves in Wupatki, Sunset Crater and Bandelier National Monument in New Mexico are mentioned in Zuni migration songs. During the migrations, the people traveled back and forth throughout the area and used 
caves as food caches and for ceremony. The blowhole was an important power-seeking spot and would remain so today if it were not so accessible to the general public. The Zuni people continue to pray and meditate here, asking spiritual Beings for assistance in their daily lives.

\subsubsection{Hopi}

The Hopi name for Wukoki means 'Big House' or 'many dwellings in one village.' Hopi advisors have stated that Wupatki was a place where people congregated for special events such as the Snake Dance, which was performed in the ball court. The Bear Clan was the first to live at Wupakti, while Wukoki figures prominently in the Walpi Snake Clan's migration story [46]. Mercer also documents Wukoki as the last residence of the Rattlesnake Society, and Hopi advisors have stated recently that the Rattlesnake Clan was the last ruling clan to occupy Wupatki [46]. Based on Hopi traditional history, anthropologists think that the Tsuutsu't (Rattlesnake Society) originated at Toko'navi, near the San Juan River, and migrants took the Snake Dance to Wupatki or Wukoki, and later to the Hopi villages and Acoma. Hopi traditions about Wupatki and Wokoki suggest the people who lived there were part of an interaction sphere that extended to the Keresan Pueblos in New Mexico. There are two other prominent Hopi religious associations with Wupatki, Lanlkont (the Basket Ceremony), and Maraw (women's societies). The Basket Ceremony is associated with events that happened at Wupatki, and the Maraw ceremony was performed in Palatwapi, "the Red Land of the South". The Hopi stopped performing this ceremony when they migrated to northern Arizona, but they reactivated it at Wupatki following a gambling dispute. People who came from Walnut Canyon often traveled to Wupatki to play a game called Totolospi [49].

The blowhole at Wukoki is seen as an important feature in the Hopi cultural landscape. Similar to the blowhole found at the Bonito Lava Flow near the Sunset Volcano, this geological feature is linked to Yaapontsa, the "Wind God." It is called Huukyangwuy Kii'at, which translates to the 'Wind's Home.' The Hopi associate the blowhole at Wupatki with the breath of Aaloosaka, whose hikwsi (breath) is always cold [49]. This Hopi story of the blowhole was published in 1947 by Hopi leader E. Nequatewa [50] in his book The Truth of a Hopi and Other Clan Stories of Shungopovi. Key in this oral history story is a plugging of the blowhole by spiritual Beings, a subsequent shift in climate to be warmer and dryer, and the reopening of the blowhole to restore the breath of Yaponcha, cool the environment, and provide rain. The oral history accounts are useful for further understanding the cultural meaning of blowholes, but it is not re/published here out of respect for contemporary Hopi sensitivities about reprinting traditional stories.

\subsection{Discussion}

The Sunset-Wupatki monuments are now interpreted by the NPS using a number of Native recommendations, many of which are in the primary visitor center at Sunset Crater. There, the volcano is discussed as a Living Homeland that has the power to symbolize essential aspects of the culture of the nine tribes who participated in the 2004 study. It is described as a place of ongoing pilgrimage and that the volcano Brings New Life. A multicultural kiosk has been provided that contains a map of the reservations of the participating tribes and a phone for listening to a tape of an elder describing the meaning of the volcano to his tribe or pueblo. The prerecorded tapes are from a specific tribe or pueblo who approved its content and uses (Figure 12).

The parks are administered by a central management NPS team, so there is a possibility of integrated Native American culturally or heritage-based management. The notion of integrating the parks as a single Wupatki-Sunset cultural landscape has not been addressed. They remain separate.

There remains an opportunity to reflect on how to improve interpretations of the past by including Indigenous cultural information and integrating interpretations of the two parks. One way would be to have such information included on the Sunset Crater Volcano 
and Wupatki websites, which contain overviews of cultural landscapes and downable materials such as trail guides. Such cultural information has been successfully integrated into other parks under NPS jurisdictions, such as Chaco Culture National Park, New Mexico and Navajo National Monument, Arizona. These are just potential ways forward towards an integrated Native voice.

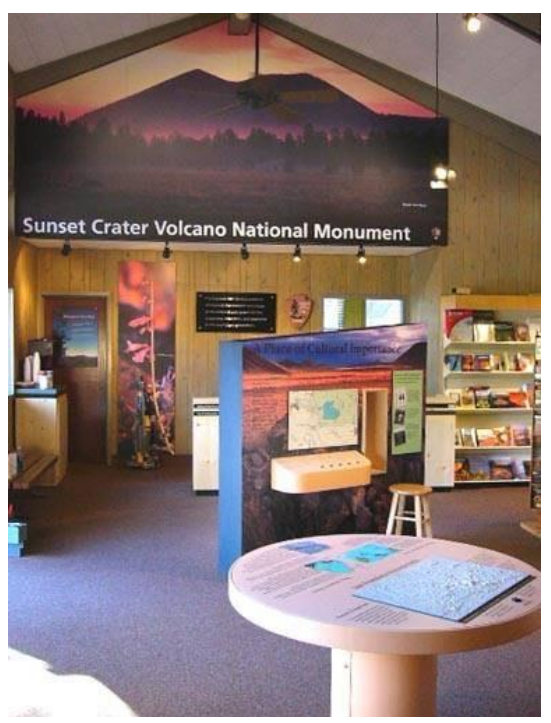

Figure 12. Kiosk in Center with Map of Reservations and Phone for Talking with an Elder from Any of the Nine Tribes.

With such a Native voice front and center in park interpretation and management, the new cap on the blowhole at Wupatki might have been reconsidered. The NPS has now placed a flagstone cap with a small opening on the blowhole in Wupatki to protect visitors who might otherwise go inside. The exit of the blowhole (Figure 13) is now engineered, which was the subject of the Hopi Yaponcha story. Partially closing the blowhole is clearly a culturally sensitive issue for the participating tribes and pueblos.

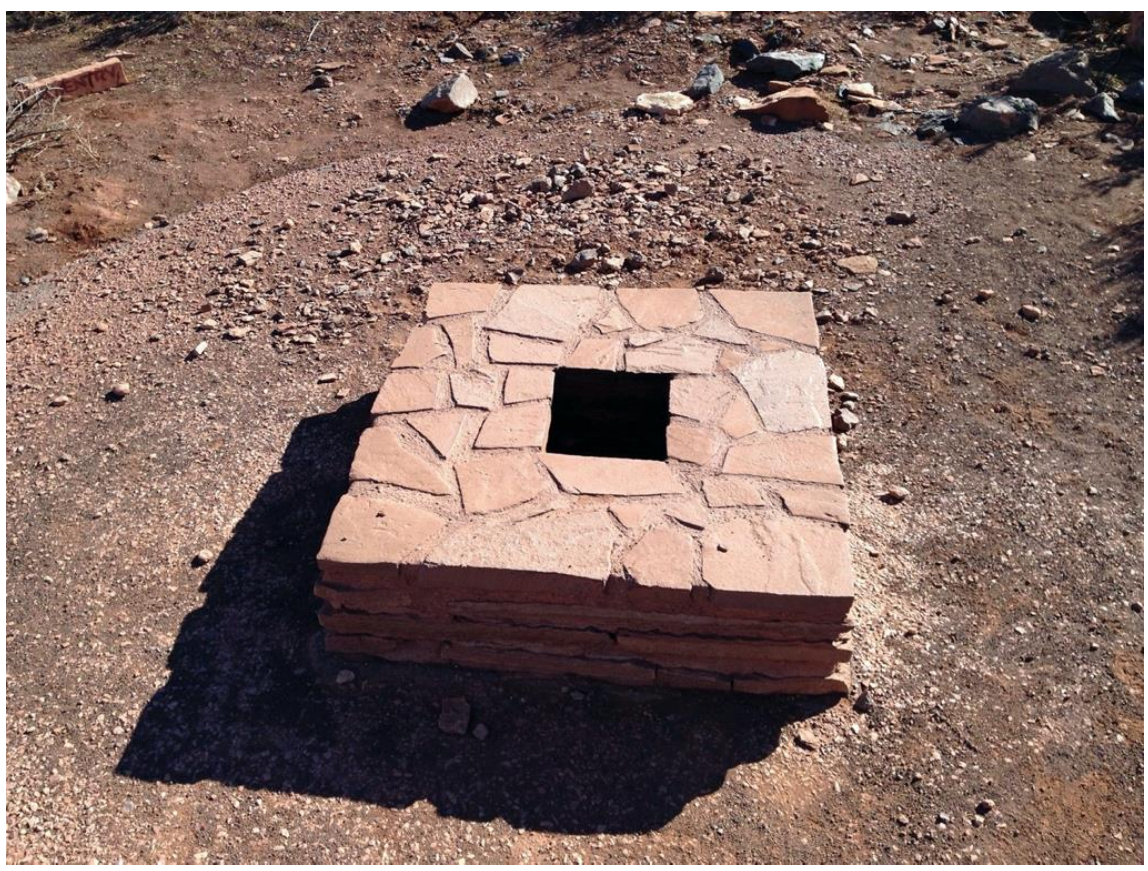

Figure 13. Wupatki Blowhole with the NPS Flagstone Cap [51]. 


\section{Ethnology}

This discussion contains ethnographic findings from other volcano ethnographic studies, which help to situate the Sunset-Wupatki findings and argue for the existence of an integrated ceremonial area or cultural landscape. Ethnology, as mentioned earlier, is the comparison of findings from different cases to reach more confident interpretations of cultural patterns than would otherwise be possible with a single case.

Here we begin with findings from Petroglyph National Monument, which is located just west of Albuquerque, New Mexico. The study was focused on a flat basalt lava flow, having some elevated cinder cones and thus is topographically similar to Sunset-Wupatki. Important for this analysis, archaeology structures and offering shrines were perceived as serving ceremonial activities conducted by pilgrims to the location, and these and other structures and artifacts were not components of residential living areas.

\subsection{New Mexico Volcanoes and Pueblo People}

The following text comes from our ethnographic report conducted at Petroglyph National Monument in New Mexico [37] (Figure 14). Ethnographic testimony provided for this report was reviewed at the time by the participating Pueblo people and is thus an official document to be used by the NPS and for this analysis. The text present here is as reviewed and approved by the tribes, so some portions have their original uncorrected English segments.

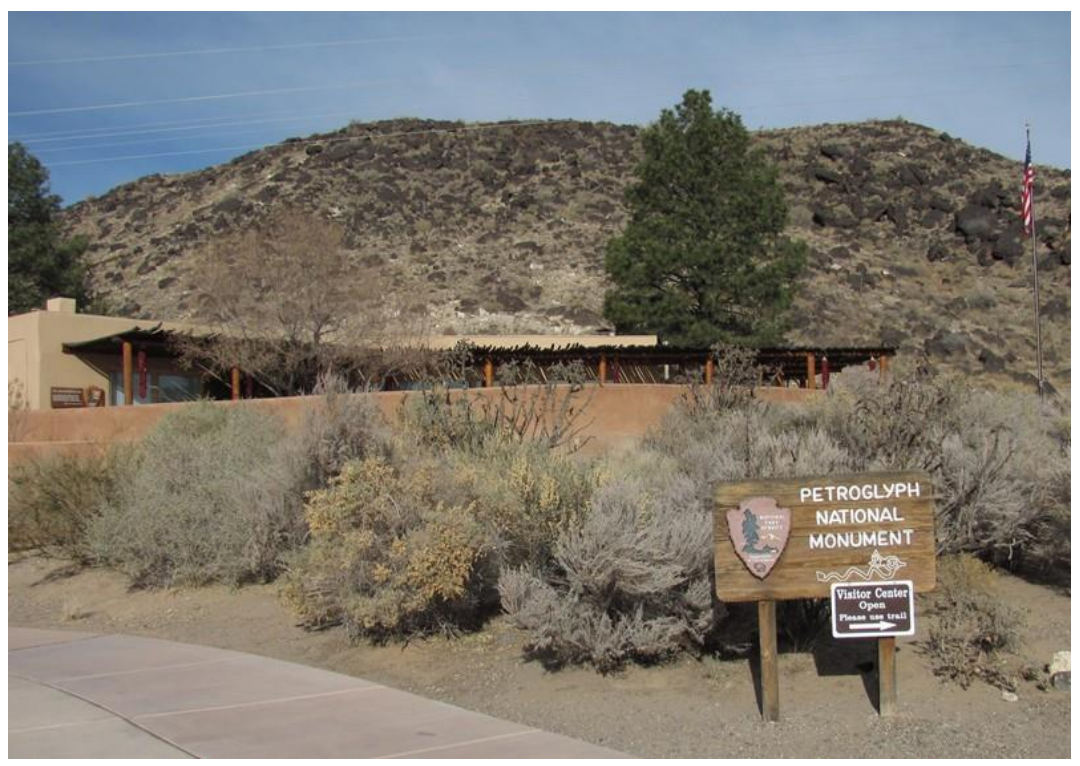

Figure 14. Petroglyph National Monument, New Mexico [52].

Pueblo consultants identified the volcanoes of Petroglyph National Monument as culturally significant to Pueblo people in two ways. The first was as a general area of spiritual importance. In discussions with seven different Pueblo groups, the entire Monument area was referred to as "the volcanoes." Sandia Pueblo consultants identified the entire area west of the escarpment as where spirit trails are located. These are trails traveled by spirits of the dead on their way to other places such as the afterlife. They feel the petroglyphs on the escarpment, the volcanoes, and the spirit trails are interrelated, forming a communication nexus to the spirit world that can be used by living people to help their prayers and medicine in this world. Some prayers and medicine ceremonies are thought to be more powerful if they can be expressed or practiced at the volcanoes. Sandia Pueblo consultants felt this was so in the past, and they know of living people who have used the volcanoes for prayers and medicine in their lifetimes. The volcanoes are also included in at 
least one Rio Grande Pueblo story regarding the Underworld. The English translation of a Pueblo name for the area is approximately Crown of the Blossom.

The second way the Pueblo consultants identified the volcanoes as culturally significant was through site-specific objects and locations. At least one, and possibly two, sacred areas were identified by three different Pueblo's consultants who visited the area. Sandia Pueblo consultants also identified the general volcano area as being included in prayers and ceremonies today. It was mentioned that prayers and prayer sticks are brought to and left in the area. Specific healing powers are attributed to the volcanoes.

In the larger context of Pueblo belief systems, all things, whether plants, animals, rocks, or other inanimate objects, are alive and have spirits. Zuni consultants pointed out that the rocks are alive so that they can take care of the plants. Zuni consultants felt that people coming to the volcano area for medicinal plants would have left offerings for the rocks and the volcanoes because of the sacred relationship between the volcanoes, the rocks, the mountains, and the medicinal plants. In keeping with Zuni Pueblo's traditions, these offerings and the medicinal plants associated with them would have been used by members of special medicine societies.

Zuni Pueblo consultants felt the volcanoes and the open central area separating them from the escarpment might contain the remnants of trails people used while traveling from various points to sacred areas in the Sandia Mountains. They pointed out that people would not simply have walked a straight line from their home to the mountains, but they would have stopped at places along the way. The volcanoes are an obvious place these travelers would have stopped, due to the unique nature of the rock outcroppings and the location of the petroglyphs along the escarpment. If they did stop at the volcanoes on these religious journeys, they would have left offerings at significant places on and around the volcanoes.

Zuni Pueblo and Zia Pueblo elders said the volcanoes were an obvious guidepost and visual marker for people traveling between sacred mountains such as the Santa Fe Mountains, the Sandia Mountains, Mt. Taylor, the Ortiz Mountains, and the Magdalena Mountains. For Pueblo people, the Sandia Mountains are sacred and contain sacred areas and shrines. Given the sacredness of the Sandia Mountains, the Zuni Pueblo consultants believed that it was highly likely that there are other specific prayer, religious, and sacred areas immediately surrounding the mountains, probably around the volcanoes.

The sacredness of the surrounding mountains is expounded upon by Ortiz [14] who gives the Tewa name of the Sandia Crest as Oku Pin or Turtle Mountain. The sacred mountains of the Tewa all have "earth navels" associated with them. These are where stone shrines are placed, thus marking where people can communicate with the spirit world. In Tewa society, the shrines also help gather the blessings of the different spiritual worlds and direct these blessings to the home village [18]. In Tewa Pueblos, pilgrimages are made to earth navel shrines located on the four sacred mountains.

Shrines identified near the Vulcan Volcano within the Petroglyph National Monument boundaries are entirely consistent with the descriptions of earth navels given by Ortiz and others for Tewa Society $[18,53,54]$. In the larger context of the Pueblo religious system, it does not matter if Pueblo people still own the sacred area. The Pueblo consultants felt that the important point was that the area is not disturbed, because some Pueblos believe that if a place is disturbed it cannot be used for religious activity. The evident levels of recreational use, vandalism, and painting of the rocks were pointed out as reasons to limit access to the area.

During our interviews, it became obvious that Pueblo people view the Petroglyph National Monument area as a whole landscape, not as a group of discrete cultural resources. The volcanoes were felt to be connected on many different spiritual and physical realms to both the escarpment petroglyphs and the nearby Sandia Mountains.

In general, Pueblo people believe that if a location is specifically connected to medicine societies or clans, and people stop using it, those clans, the prayers, the songs, and the items associated with the site can disappear from the culture. The Pueblo consultants felt 
that protecting these places so that they can continue to be used for religious purposes is essential to their people keeping their religion and their culture. Zuni Pueblo consultants pointed out that it is very difficult to recover what is lost once the use of a place is lost, and this can cause spiritual items to disappear forever. It was made clear to us during the site visits and interviews that Pueblo people continue to know how to interpret the importance of an area. A Native American person does not have to be the original user of the cultural resource or be from the original users' tribe to have a culturally based understanding of how an area was used in the past.

A few miles outside of the monument near the Rio Grande River is an especially large collection of structures associated with a major Classic Period Pueblo (AD 1300 - 1700) [55]. Zuni interpretations of this Pueblo are especially useful for understanding its ceremonial meanings and by implication of those of the structures at Wupatki [35].

Zuni Pueblo consultants (all members of the Zuni Cultural Resources Advisory Team) said there should not be any excavation at the Piedras Marcadas Ruin because these kinds of ruins had sacred components for the Pueblo people. They felt that the former inhabitants of the now ruined pueblo chose that location for certain reasons, some of which would have been religious and spiritual in nature. Therefore, the location itself had sacred meaning to them and should be respected as a sacred site.

The Piedras Marcadas Ruin was not incorporated into the Petroglyph National Monument, so its cultural significance for the New Mexico Pueblo people was neither interpreted by the NPS nor protected along with the volcanoes.

\subsection{Little Springs Volcano and Sherd Rocks}

The second ethnological comparison case is based on ethnographic studies [38,56] funded by U.S. Federal agencies that have been centered on the Uinkaret Volcanic Field (UVF) (the dark areas in the center of Figure 15) in a region defined by northern Arizona, Colorado River, and the western Grand Canyon. Here, hundreds of volcanic events occurring over millions of years developed and shaped this almost unique topographical landscape [57].

The UVF can be further understood through the cultural lens of Southern Paiute land epistemology, especially as this is held by the Shivwits Paiutes, San Juan Paiutes, Kaibab Paiute, and Uinkaret/Uyu'naits Paiutes (translated as the Arrow Quiver people) [58], who were the aboriginal inhabitants of these lands. The resulting cultural interpretations and behavioral responses to these volcanic places now make up a spatially extensive and complex cultural landscape [56].

The Southern Paiute cultural landscape that both surrounds and culturally interprets the UVF goes back in time to what Southern Paiute people call the Time of Creation or what legally is called Time Immemorial. Southern Paiute people maintain that they are the people who were created for and with this cultural landscape. That act of Creation formed a mutual set of obligations and responsibilities between Paiute people and this living natural world, especially the volcanoes.

The more than $2438 \mathrm{~m}$ (8000 ft) in elevation volcano called Mount Trumbull (recorded as yïv ${ }^{W}{ }^{\prime}$ 'ykarïIÏ-Pine Peak, Mount Trumbull in 1910) [58], is located about 22.5 km (14 mi) north of the Colorado River and is in the center of the Uinkaret Volcanic field. This mountain is a central feature of both this landscape and the culture of the Indigenous people who have lived in this area since Creation or what is legally called Time Immemorial (Figure 16). 


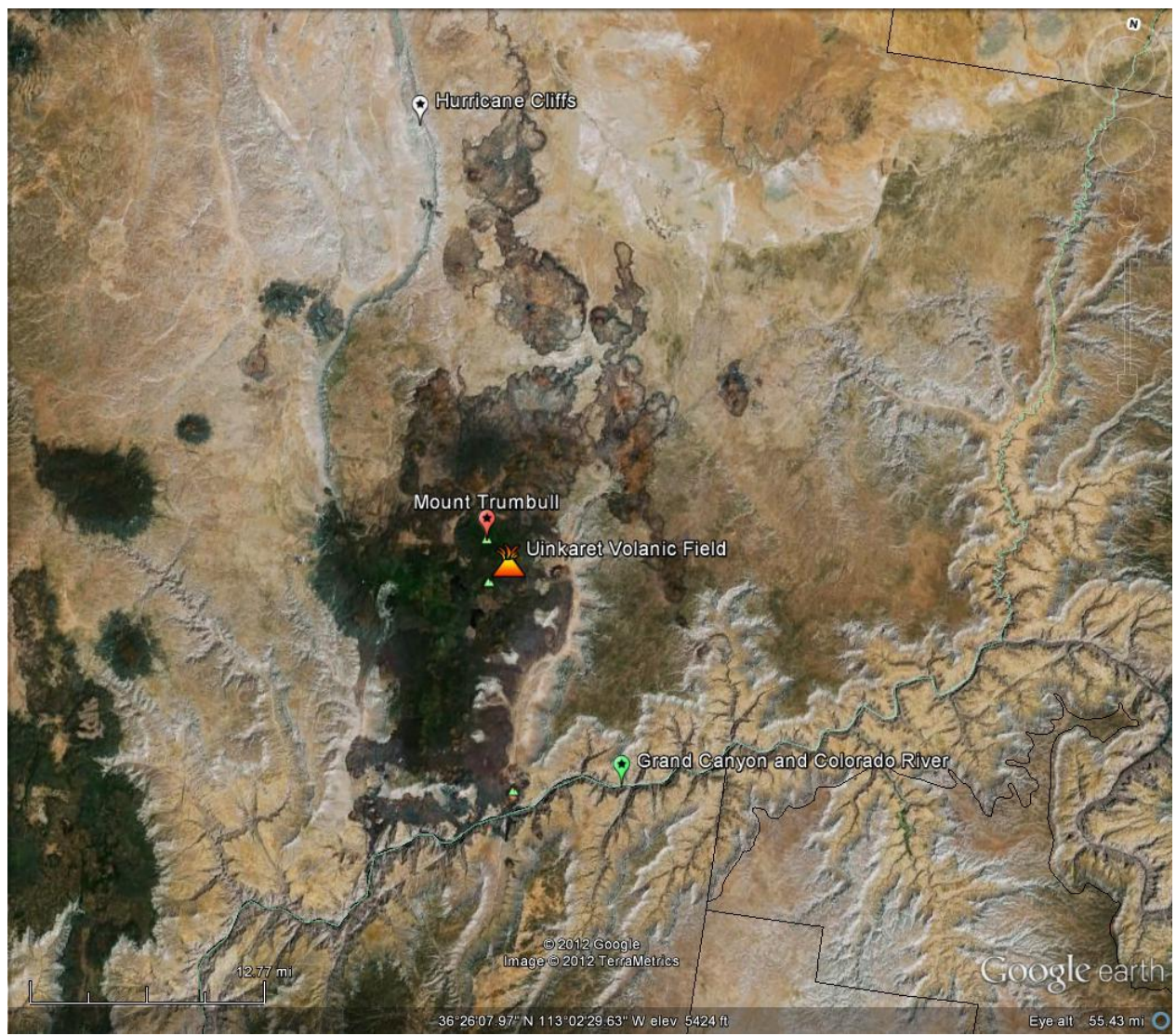

Figure 15. The Uinkaret Volcanic Landscape, Grand Canyon, and Colorado River.

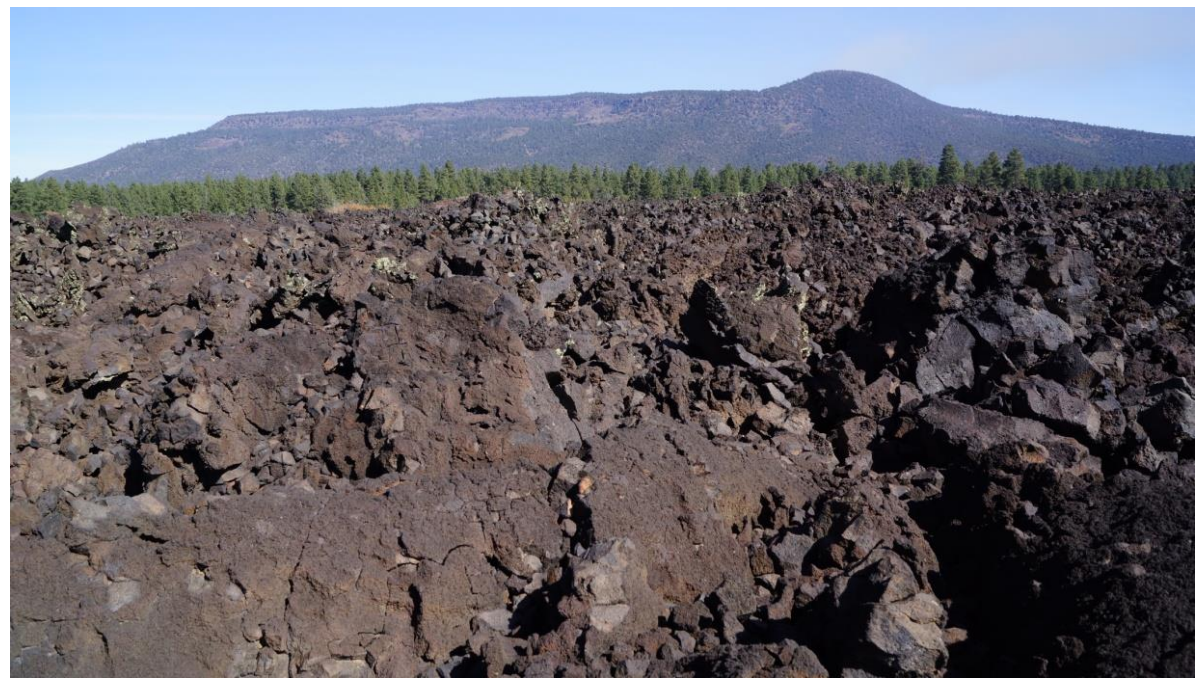

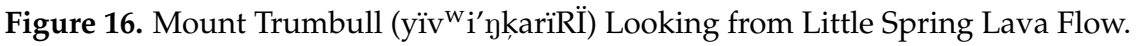

The ethnographic studies were funded in two parts by the Bureau of Land Management (BLM). The first study was funded in 2005, and a second was funded in 2012. Parashant National Monument was established, incorporating the Little Spring Lava flow, Mount Trumbull, and much of the UVF. These areas are now jointly managed by the BLM and NPS as Grand Canyon-Parashant National Monument.

The initial ethnographic study involved tribal cultural representatives from the Kaibab Band of Paiutes Indians, Moapa Band of Paiute Indians, Paiute Indian Tribe of Utah, and the San Juan Southern Paiute tribe. It was broad in scope, dealing with both specific places 
and cultural landscapes in the region north of the Colorado River. The second field study was focused on Kaibab Paiute relationships with the Little Springs volcanic event, which occurred about 1075 AD in the UVF.

The youngest volcanic rocks in the UVF were produced when a double cinder cone (or single mountain) formed about $3 \mathrm{~km}$ ( $2 \mathrm{mi}$ ) south of Mount Trumbull (Figure 17). The cinder mountain (or cones) rose on a narrow volcanic ridge. The cinder mountain was taller than its current tallest point of $2094 \mathrm{~m}$ or at least $44 \mathrm{~m}$ above the current ridge. The ridge divides two valleys: the one to the north slopes down $35 \mathrm{~m}$ to about $2015 \mathrm{~m}$, and the one to the south slopes down ridge $159 \mathrm{~m}$ to about $1891 \mathrm{~m}$. Both valleys are surrounded, and thus defined, by old volcanoes that are about $2075 \mathrm{~m}$ high. After the cinder mountain (cones) rose, the magma inside it (them) burst through the north and south sides of the cinder mountain and rapidly flowed down hill into the neighboring valleys. When the magma inside the cinder mountain broke through, the cone(s) were largely destroyed. Some remnants of the cinder mountain, however, can still be found on the surface of what is now called the Little Spring Lava Flow. It is named after a nearby permanent spring called on USGS maps Little Spring. This water source is one of only three permanent springs in the Uinkaret Plateau.

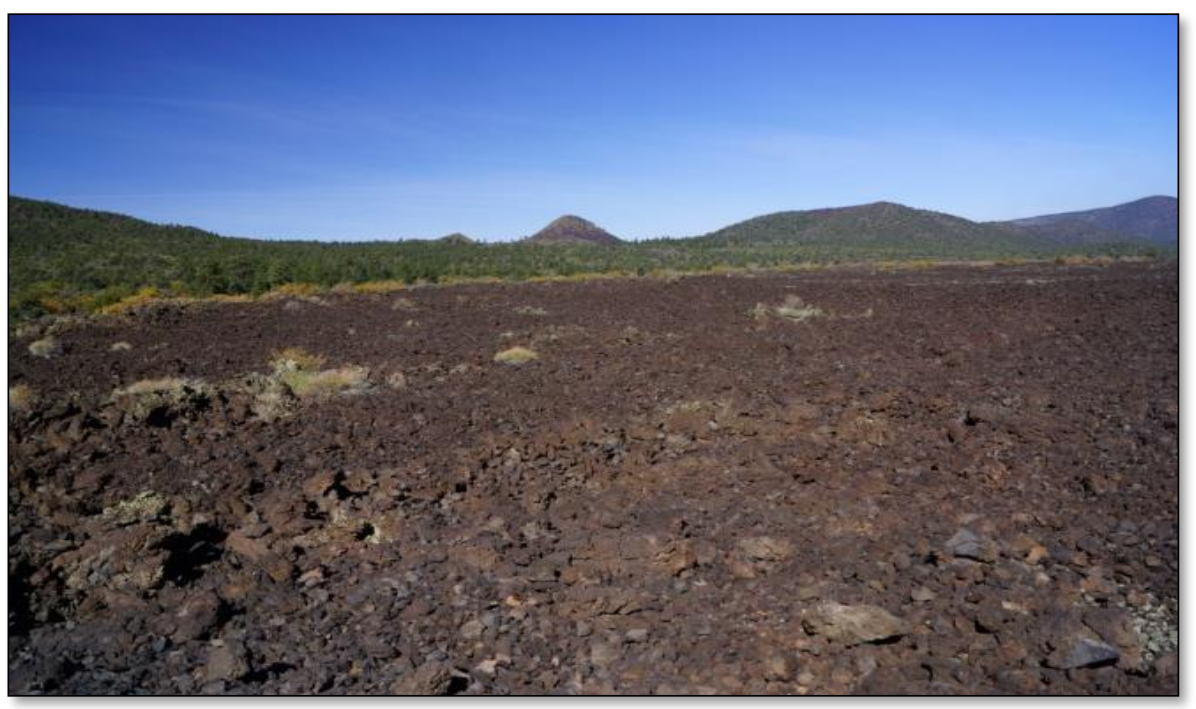

Figure 17. Little Spring Cinder Cone on Horizon Seen from End of the Southern Lobe.

The Little Spring Lava Flow event is dated with archaeology at about 1075 AD [59,60]. Although standard volcanic dating procedures were followed, they largely failed to provide a useful eruption date, thus the estimated dates for the flow are based on Indian pottery found in Indian made lava/pottery rocks, called sherd rocks, which are volcanic scoria containing pottery fragments (Figures 18 and 19). The lava pottery stones, or sherd rocks, subsequently were moved some distance from the lava flow and made into a series of structures that were used in ceremony according to the Paiute representatives.

These sherd rocks were created ceremonial artifacts made by combining various styles of pottery with the magma/lava that bubbled up at hornitos located well out on the lava flow itself. The style and designs of the pottery used is well recognized and dated by archaeology excavation. Other criteria supporting this eruption date are the freshness of the basalt flow surface, its rough character, and its lack of weathering. The Little Springs Lava Flow has many of the same characteristics as the well-dated 1000-year-old basalt flows at Sunset Crater National Monument near Flagstaff, Arizona. It is not clear whether or not the Little Springs eruption event occurred before or after the Sunset Crater event. Native spiritual leaders responded to both events in similar ways, producing corn rocks at one and sherd rocks at the other. 


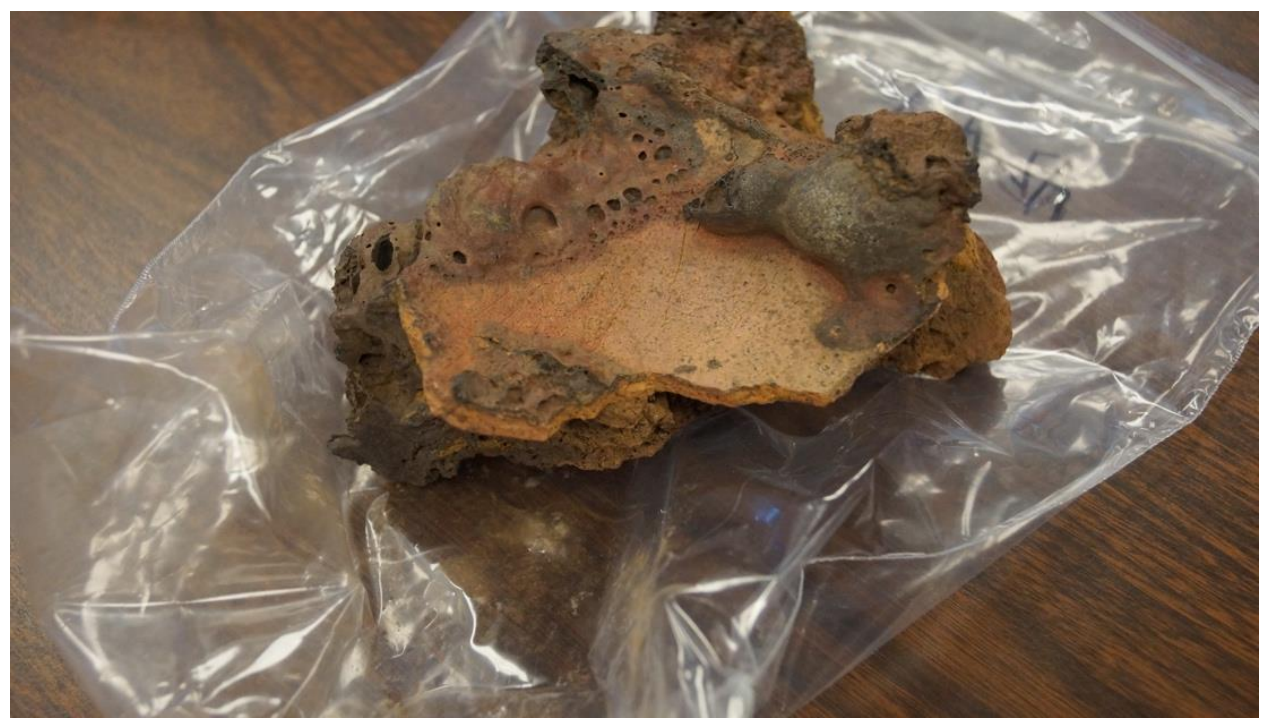

Figure 18. Sherd Rock found at Little Springs.

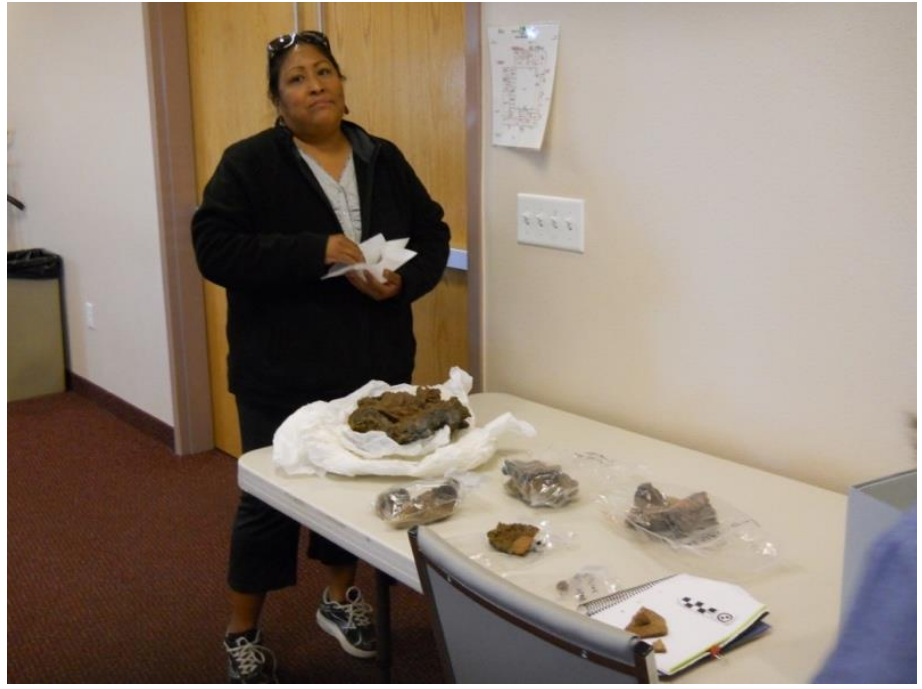

Figure 19. Southern Paiute Tribal Representative Examining the Sherd Rocks.

Details of just how the Little Spring event occurred are important because there are multiple theories regarding just how and why the pots and the hornitos came to be together. The basalt lava of the Little Spring event originated from two closely associated events.

Today, almost a thousand years later, there is no soil cover and very little vegetation on the surface of the two flows. Vegetation tends to grow only on the scattered remnants of the cinder scoria mountain materials that were rafted from the vent areas. The edges of the two flows stand as tall walls of cooled lava in stark contrast with the surrounding valleys and surrounding mountains.

Scholars agree that the Little Springs event was special because Native Americans came to various hornito spatter vents in the active lava flow(s) and made lava/pottery rocks. It is also important that, after the eruption and ceremony, Native Americans made miles of trails on the two lava flows and hundreds of round low wall structures. Given the blocky surface of the lava flows, they needed to transport clean cinders in large baskets to the top of the a'a lava flows. Portions of the remaining cinder mountain subsequently became the material of choice used by the Native Americans to make this elaborate system of trails, because it was without dirt and easy to carry. It is estimated that $8 \mathrm{~km}$ or about 4.7 miles of trails were built on the two rough lava flows. It is estimated that thousands of 
trips carrying cinders in a large basket on the backs of Native Americans were needed to make the trails and foundations for the round structures.

The Paiute burden basket with a tumpline worn across the forehead is the only known carrying device that would have been used to transport basket loads of materials. A typical Paiute burden basket is $76 \mathrm{~cm}$ high and has a $71 \mathrm{~cm}$ wide diameter at top with a pointed bottom. We estimate that this would hold about $100 \mathrm{~L}$ ( 2.8 bushels). The known trails have been estimated at $8 \mathrm{~km}$ (or 4.7 miles). If we look at how many cinders it would take to make a meter/yard of these trails, we estimate it would take three burden basket loads per yard of trail. The trails are $8 \mathrm{~km}$ long, which is $8000 \mathrm{~m}$ (8748 yards). When multiplied by three loads per meter, this suggests that about 26,244 round trips were needed to make these trails.

The lava pottery stones created during the eruption were moved from the lava flows and incorporated into a series of structures that were used in ceremony, according to the Paiute representatives and archaeologists [38].

Pilgrimages to Little Spring, the only remaining spring, and surrounding volcanic landscape has continued down to modern times [38]. The Kaibab Paiute people have a traditional song about the event, which they sing when they bathe in the spring waters.

The ceremonial structures that incorporated the sherd rocks are similar to those at Sunset Crater, which incorporated the corn rocks. The cultural meaning and landscape components of the UVF before and after the event, however, is a matter in some scholarly debate. From a Native perspective, however, their response to this event is a matter of cultural importance and evidence that they understand the physical dimensions of volcanic events.

\subsection{On Massive Stones at Hovenweep}

This third ethnological case is about the multistoried and finely constructed structures that are now protected as a series of noncontiguous components of Hovenweep National Monument on the Utah-Colorado border near Cortez, Colorado. These structures and their purposes have been interpreted by culturally affiliated tribes and pueblos as part of an NPS funded Ethnographic Overview and Assessment [61]. Each of the park units are located at the head of a small canyon where a spring emerges. At these locations, one or more multistory structures were constructed on top of massive stones (Figure 20).

Below each structure was a path to the canyon floor where one or more kivas were located. Around the edge of the shallow canyons were other multistory structures. All structures had small holes in their walls, and it is assumed that each had a roof that was used for activities (Figure 21). A consensus among the tribal representatives was that the various structures were used by a social class of religious priests. They managed through balancing ceremonies both the weather and the tens of thousands of dry-land farmers who lived in large communities located from dozens to hundreds of miles from these structures.

The area was used for farming from AD 500 to AD 1300 and is located in what is termed the Mesa Verde World [62-64]. Prayers asking for good farming weather and social balance traveled to the energy and power places of the earth and sky. They traveled from the kivas through the ground into the spring and from there into its hydrological headwaters in the surrounding Sky Island mountains. Prayers also traveled in a direct line to the sky and clouds and elsewhere, such as the Colorado River and the Sea of Cortez. The Hovenweep structures were for collective religious ceremonies and were not residential farm homes, according to most of the tribal and pueblo representatives. 


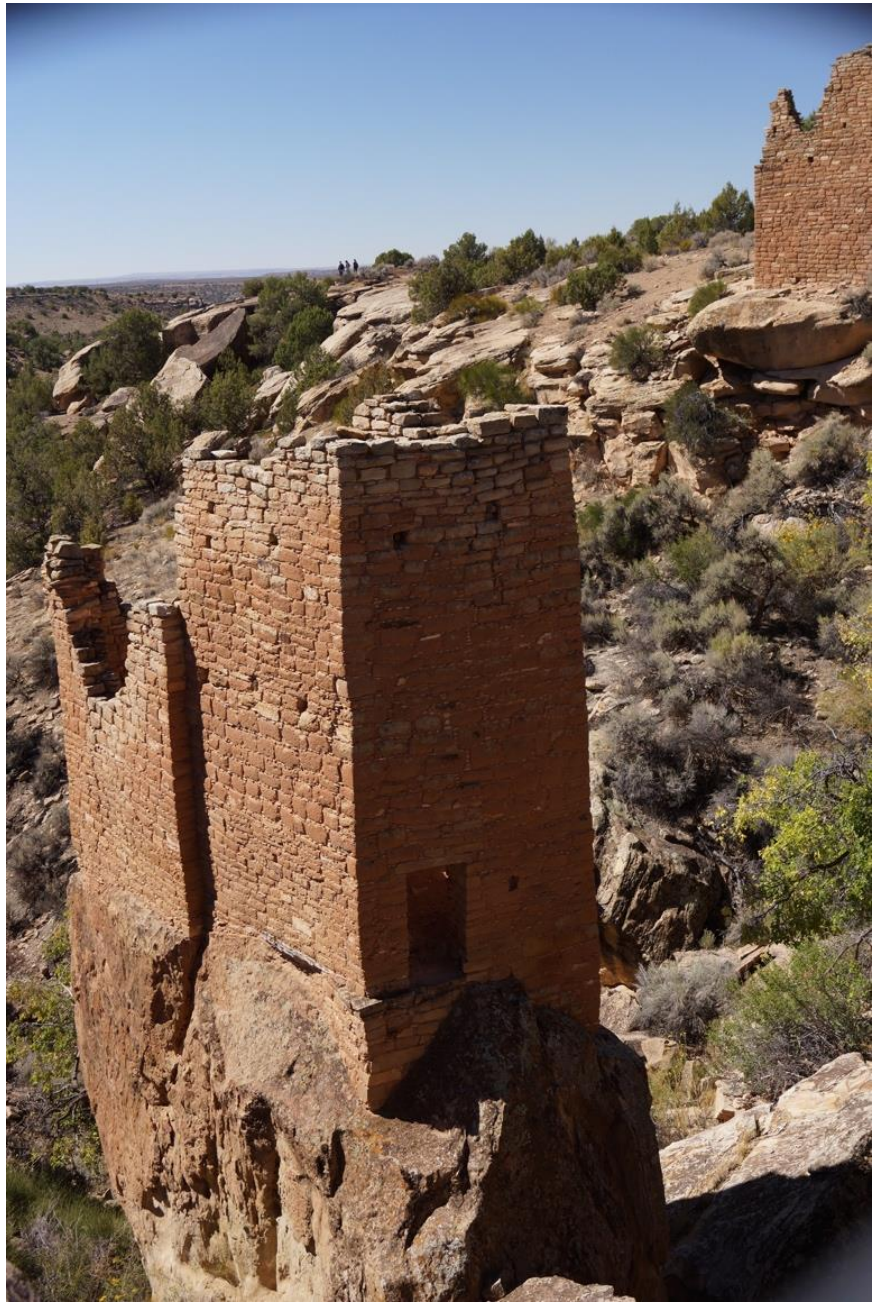

Figure 20. Square Tower atop Large Stone at the Head of a Canyon next to a Spring at Hovenweep.

Critical for the discussion of Sunset-Wupatki is the interpretation that the prayers and messages travel from high points in the structures and downward through the large stones on which the structures were built and then into the ground. We assume the Wupatki prayer paths would also travel from the structures to the nearby blowholes, which flow back into the volcano and then somewhere from there.

\subsection{Discussion}

The ethnographic site-specific findings from Little Spring, Hovenweep, and Petroglyph national monuments are comparable and thus of ethnological value for defining Native American interpretations of Sunset-Wupatki. All involved integrated ceremonial landscapes were used and established since Time Immemorial. These landscapes have lasted through time as significant cultural components of contemporary tribal and pueblo people.

Specifically noted in these ethnographic comparisons are that (1) volcanoes are considered a place and action of rebirth for the earth, (2) both ancient and active lava flows were respectively incorporated into native ceremony, (3) ceremonial structures were positioned to facilitate prayers to other locations, and (4) corn rocks and sherd rocks reflect a shared cultural pattern for interacting with volcanoes among participating tribes and pueblos. These interpretations, which have all been approved during the production, review, and public issuance of the technical reports, thus stand as actional information for the NPS managers as they modify both their resource management plans and public education programs about these parks. Ultimately, it will be the management's decision for each NPS 
monument as to whether these Native interpretations properly expand the defined mission of the park.

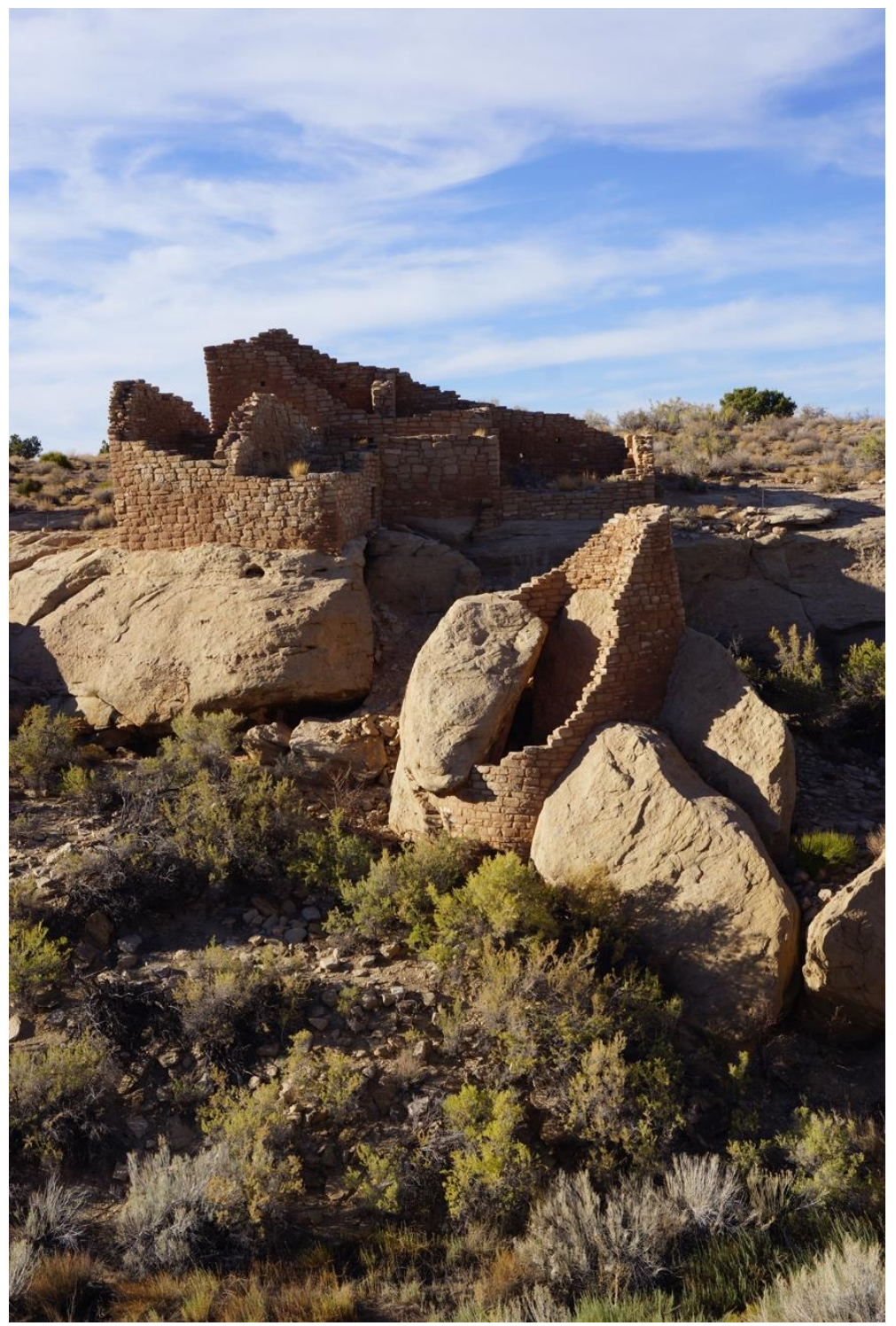

Figure 21. Round Towers Built Around Large Stones at a Canyon Head next to the Spring at Hovenweep.

\section{Conclusions}

Native American people have lived in North America for more than 23,000 years, during which time they learned about, attached themselves to, and developed relationships with the natural resources. Volcanoes are especially important because they are both events of earth rebirth and promises of new understandings for better healing through medicine, resolving community tensions, and world balancing, including large scale fluctuations in fauna, flora, and climate. Volcanoes are not just there on the landscape but emerged as part of a plan established at Creation. They are alive and talk with people who understand how to properly talk with them as living beings.

The NPS talks with tourists just as Indigenous people talk with volcanoes. Essential in these conversations are common data and process understandings, which are the basis of all environmental communication $[65,66]$. All speakers need to share clear understandings of (1) what is being discussed, (2) how these are influenced by known forces, and (3) the role of humans in this situation. An Epistemological Divide [67] occurs when speakers from different 
cultures (or cultural traditions) attempt to communicate about an environment that is different in any of these three aspects. Therefore, when Indigenous people express the view that a volcano is a living Being sent to talk with them, this constitutes an impossible epistemological divide for a speaker from a western tradition where volcanoes are inert and only subject to geological forces. Earlier, we argued that multivocality is the only sustainable interpretative path for land management agencies who are educating a touring population about a Native heritage volcano. Native Americans involved in our NPS ethnographic studies agreed that it is not necessary for the NPS to accept as true what Native Americans believe, but it is essential to tell in park interpretative settings both stories side by side with equal accuracy $[43,63]$.

Author Contributions: The authors of this research analysis are R.S. and K.V.V. They made equal contributions to the conceptualization, data analysis, document reviews, and writing of the current paper. All authors have read and agreed to the published version of the manuscript.

Funding: External research funding for the 23 foundation studies was provided by various U.S. Federal Agencies; however, this paper was prepared without external funding.

Data Availability Statement: This paper is based on 23 previous funded research studies, which are listed in Appendix A. These technical reports are available at Richard Stoffle Collection in the University of Arizona Campus Repository. https:/ / repository.arizona.edu/handle/10150/270115, accessed on 20 January 2022.

Acknowledgments: The UofA ethnographers who assisted in interviewing and recording information for the two primary documents used in this analysis are Richard Stoffle, Rebecca Toupal, Shawn Kelly, Jill Dumbauld, Nathan O'Meara, and Christopher Basaldu. Kathleen Van Vlack, and Fletcher Chmara-Huff participated in document analysis and technical report production. The fol-lowing tribal and pueblo representatives participated in the 2004 Ethnographic Overview and Assessment study. Pai Roland Manakaja (Havasupai), Katherine Marquez (Yavapai Apache), Loretta Jackson, (Hualapa), Malinda Powskey, (Hualapai), Ila Bullets, (Kaibab Paiute), Warren Mayo, (Kaibab Paiute), Gevene Savela, (Kaibab Paiute), Henry Whiskers, (San Juan Southern Pai-ute), Stanley Whiskers, (San Juan Southern Paiute), Leland Kaamasee, (Cultural Advisory Team Member, Zuni), Octavius Seowtewa, (Cultural Advisory Team Member, Zuni), Perry Tsadiasi, (Cultural Advisory Team Member, Zuni), Jerome Zuni, (Supervisory Archaeologist, Zuni), Rozella Hines, (Yavapai Apache), Levi DeHose, (White Mountain Apache), Jeanette Cassa, (San Carlos Apache), Vincent Randall, (Camp Verde/Payson, Apache).

Conflicts of Interest: The authors declare no conflict of interest.

\section{Appendix A}

Table A1. Ethnographic studies involving volcanoes conducted with Sunset-Wupatki participants.

\begin{tabular}{|c|c|c|c|c|c|c|c|c|}
\hline \multicolumn{2}{|r|}{ Project Title } & \multirow[t]{2}{*}{ Year } & \multicolumn{6}{|c|}{ Ethnic Group } \\
\hline & & & Zuni & Paiute & $\begin{array}{l}\text { Acoma } \\
\text { Other } \\
\text { Pueblos }\end{array}$ & Ute & Hopi & $\begin{array}{l}\text { Apache } \\
\text { Navajo }\end{array}$ \\
\hline 1 & $\begin{array}{c}\text { Toyavita Piavuhuru Koroin "Canyon of Mother Earth": } \\
\text { Ethnohistory and Native American Religious Concerns in } \\
\text { the Fort Carson Pinyon Canyon Maneuver Area. (Stoffle } \\
\text { et al. 1984) }\end{array}$ & 1984 & & & $X$ & $X$ & & $X$ \\
\hline 2 & $\begin{array}{c}\text { Annual Report, Native American Cultural Resource } \\
\text { Studies, } \\
\text { Yucca Mountain, Nevada. } \\
\text { (Stoffle et al. 1988) }\end{array}$ & 1988 & & $X$ & & & & \\
\hline 3 & $\begin{array}{c}\text { Petroglyph National Monument Rapid Ethnographic } \\
\text { Assessment Project. Prepared for New Mexico State } \\
\text { Historic Preservation Office and Southwest Regional } \\
\text { Office of the National Park Service. (Evans, Stoffle, } \\
\text { and Pinel 1993). }\end{array}$ & 1992 & $X$ & & $X$ & & & \\
\hline
\end{tabular}


Table A1. Cont.

\begin{tabular}{|c|c|c|c|c|c|c|c|c|}
\hline \multicolumn{2}{|r|}{ Project Title } & \multirow[t]{2}{*}{ Year } & \multicolumn{6}{|c|}{ Ethnic Group } \\
\hline & & & Zuni & Paiute & $\begin{array}{l}\text { Acoma } \\
\text { Other } \\
\text { Pueblos }\end{array}$ & Ute & Hopi & $\begin{array}{l}\text { Apache } \\
\text { Navajo }\end{array}$ \\
\hline 4 & $\begin{array}{c}\text { Ethnographic Assessment Summary For Proposed } \\
\text { On-Airport Access Road, } \\
\text { Double Eagle II Airport. } \\
\text { (Evans and Stoffle 1993). }\end{array}$ & 1992 & $X$ & & $X$ & & & \\
\hline 5 & $\begin{array}{c}\text { Santa Fe Ski Basin Proposed Expansion Ethnographic } \\
\text { Assessment } \\
\text { (Evans, Stoffle, and Kraus 1993) }\end{array}$ & 1993 & $X$ & & $X$ & & & \\
\hline 6 & Fajada Butte Ethnographic Study(Stoffle et al. 1994) & 1994 & $\mathrm{X}$ & & $\mathrm{X}$ & & $X$ & $X$ \\
\hline 7 & $\begin{array}{c}\text { Grand Canyon Ethnographic Studies } \\
\text { (Stoffle et al. 1994; Stoffle et al. 1995A; Stoffle et al. } \\
\text { 1995B) }\end{array}$ & 1994 & & $X$ & & & & \\
\hline 8 & $\begin{array}{c}\text { Southern Paiute Cultural Resources Study at Zion NP and } \\
\text { Pipe Spring NM } \\
\text { (Stoffle et al. 1999) }\end{array}$ & 1999 & & $x$ & & & & \\
\hline 9 & $\begin{array}{l}\text { Storied Rocks: American Indian } \\
\text { Inventory and Interpretation of } \\
\text { Rock Art on the Nevada Test Site. } \\
\text { (Zedeño and Stoffle eds. 1999) }\end{array}$ & 1999 & & $\mathrm{X}$ & & & & \\
\hline 10 & $\begin{array}{c}\text { Ha'tata (The Backbone of the River): American Indian } \\
\text { Ethnographic Studies Regarding the Hoover Dam Bypass. } \\
\text { (Stoffle et al. 2000) }\end{array}$ & 2000 & $X$ & $x$ & & & $x$ & \\
\hline 11 & $\begin{array}{c}\text { The Three Parks Project (Zedeño, Schrag-James, and } \\
\text { Basaldu 2001) }\end{array}$ & 2001 & $X$ & & $X$ & & $\mathrm{X}$ & $X$ \\
\hline 12 & $\begin{array}{l}\text { Cultural Affiliation Study of Navajo N. M., Sunset Crater } \\
\text { Volcano N. M., Walnut Canyon N. M., and Wupatki N. M. } \\
\text { (Toupal and Stoffle 2001) }\end{array}$ & 2001 & $X$ & $X$ & & & $X$ & $X$ \\
\hline 13 & $\begin{array}{c}\text { East of Nellis: Cultural Landscapes of the Sheep and } \\
\text { Pahranagat Mountain Ranges } \\
\text { (Stoffle et al. 2002) }\end{array}$ & 2002 & & $X$ & & & & \\
\hline 14 & $\begin{array}{c}\text { Ethnographic Assessment of Kaibab Paiute Cultural } \\
\text { Resources: The Grand Staircase-Escalante National } \\
\text { Monument, Utah. (Stoffle et al. 2004) }\end{array}$ & 2004 & & $X$ & & & & \\
\hline 15 & $\begin{array}{c}\text { Traditional Resource Use of the } \\
\text { Flagstaff Area Monuments(Toupal at al. 2004) }\end{array}$ & 2004 & $X$ & $X$ & & & & $X$ \\
\hline 16 & $\begin{array}{c}\text { Yanawant: Paiute Places and Landscapes in the Arizona } \\
\text { Strip(Stoffle et al. 2005) }\end{array}$ & 2005 & & $X$ & & & & \\
\hline 17 & $\begin{array}{c}\text { Bandelier National Monument A Study of Natural } \\
\text { Resource Use among Culturally Affiliated Pueblo } \\
\text { Communities } \\
\text { (Stoffle et al. 2007) }\end{array}$ & 2007 & $X$ & & $X$ & & & \\
\hline 18 & $\begin{array}{c}\text { Black Mountain: Traditional Uses of a Volcanic Landscape } \\
\text { (Stoffle et al. 2009) }\end{array}$ & 2009 & & & & & & \\
\hline 19 & $\begin{array}{l}\text { Tonto National Monument } \\
\text { Ethnographic Study } \\
\text { (Stoffle et al. 2009) }\end{array}$ & 2009 & $x$ & & & & $X$ & $X$ \\
\hline 20 & $\begin{array}{c}\text { Unav-Nuquaint: Little Springs Lava Flow } \\
\text { Ethnographic Investigation } \\
\text { (Van Vlack et al. 2013) }\end{array}$ & 2013 & & $X$ & & & & \\
\hline 21 & $\begin{array}{c}\text { Canyonlands National Park Ethnographic Overview and } \\
\text { Assessment } \\
\text { (Stoffle et al. 2017) }\end{array}$ & 2017 & $X$ & $X$ & & $X$ & $X$ & $X$ \\
\hline
\end{tabular}


Table A1. Cont.

\begin{tabular}{|c|c|c|c|c|c|c|c|c|}
\hline \multicolumn{2}{|r|}{ Project Title } & \multirow[t]{2}{*}{ Year } & \multicolumn{6}{|c|}{ Ethnic Group } \\
\hline & & & Zuni & Paiute & $\begin{array}{l}\text { Acoma } \\
\text { Other } \\
\text { Pueblos }\end{array}$ & Ute & Hopi & $\begin{array}{l}\text { Apache } \\
\text { Navajo }\end{array}$ \\
\hline 22 & $\begin{array}{c}\text { Nellis Air Force Base Legislative Environmental Impact } \\
\text { Assessment } \\
\text { (Stoffle et al. 2018) }\end{array}$ & 2018 & & $\mathrm{X}$ & & & & \\
\hline 23 & $\begin{array}{c}\text { Hovenweep National Monument Ethnographic Overview } \\
\text { and Assessment } \\
\text { (Stoffle et al. 2019) }\end{array}$ & 2019 & $X$ & $\mathrm{X}$ & $\mathrm{X}$ & $\mathrm{X}$ & $\mathrm{X}$ & $\mathrm{X}$ \\
\hline & Total Number of Projects Per Tribe or Ethnic Group & & 12 & 14 & 8 & 3 & 7 & 8 \\
\hline & Grand Total & & & & 5 & & & \\
\hline
\end{tabular}

\section{References}

1. Keller, R.; Turek, M. American Indians and National Parks; University of Arizona Press: Tucson, AZ, USA, 1999.

2. West, P.; Brechin, S. Resident Peoples and National Parks; University of Arizona Press: Tucson, AZ, USA, 1991.

3. Hough, J. The Grand Canyon National Park and the Havasupai People: Cooperation and Conflict. In Resident Peoples and National Parks: Social Dilemmas and Strategies in International Conservation; West, P., Brechin, S., Eds.; University of Arizona Press: Tucson, AZ, USA, 1991; pp. 215-230.

4. Weber, W. Enduring Peaks and Changing Cultures: The Sherpas and Sagarmatha (Mount Everest) National Park. In Resident Peoples and National Parks: Social Dilemmas and Strategies in International Conservation; West, P., Brechin, S., Eds.; University of Arizona Press: Tucson, AZ, USA, 1991; pp. 206-214.

5. Weaver, S. The Role of Aboriginals in the Management of Australia's Cobourg (Gurig) and Kakadu National Parks. In Resident Peoples and National Parks: Social Dilemmas and Strategies in International Conservation; West, P., Brechin, S., Eds.; University of Arizona Press: Tucson, AZ, USA, 1991; pp. 311-322.

6. National Park Service. National Park System Sees More than 330 Million Visits. Available online: https://www.nps.gov/orgs/12 07/02-28-2018-visitation-certified.htm (accessed on 29 December 2021).

7. Brocx, M.; Semeniuk, V. Geoheritage and Geoconservation-History, Definition, Scope and Scale. R. Soc. West. Aust. 2007, 90, 53-87.

8. Vincent, C.H.; Hanson, L. National Monuments and the Antiquities Act; Report Number 41330; Congressional Research Service: Washington, DC, USA, 2021.

9. Ruppert, D.; Smythe, C. National Park Service Approaches to Connecting Indigenous Cultural and Spiritual Values to Protected Places. In Indigeneity and the Sacred: Indigenous Revival and the Conservation of Natural Sites in the Americas; Sarmineto, F., Hitchner, S., Eds.; Berghahn: New York, NY, USA, 2015; pp. 133-160.

10. Stoffle, R.; Sittler, C.; Van Vlack, K.; Pickering, E.; Lim, H. Living Universe or GeoFacts: Stone Arches in Utah National Parks: Epistemological Divides in Heritage Environmental Communication. Int. J. Intang. Herit. 2020, 15, $15-27$.

11. Albert, M.; Bernecker, R.; Rudolff, B. Understanding Heritage: Perspectives in Heritage Studies No. 1; Walter De Gruyter: Berlin, Germany, 2013.

12. Albert, M.; Bandarin, F.; Roders, A. Going Beyond: Perceptions of Sustainability in Heritage Studies No. 2; Springer International: Cham, Switzerland, 2017.

13. Albert, M.; Ringbeck, B. 40 Years World Heritage Convention: Popularizing the Protection of Cultural and Natural Heritage No. 3; Walter De Gruyter: Berlin, Germany, 2015.

14. Errami, E.; Brocx, M.; Semeniuk, V. Geoheritage to Geoparks-Case Studies from Africa and Beyond; Springer: Amsterdam, The Netherlands, 2015.

15. Dvorak, J. Macroscope: Volcano Myths and Rituals. Am. Sci. 2007, 95, 8-9. [CrossRef]

16. Sheets, P.; Grayson, D. Volcanic Activity and Human Ecology; Academic Press: New York, NY, USA, 1979.

17. Spoon, J. The "Visions of Pele" Competition and Exhibit at Hawai'i Volcanoes National Park. J. Herit. Steward. 2007, 4, 72-74.

18. Ortiz, A. The Tewa World: Space, Time, Being, and Becoming in a Pueblo Society; University of Chicago Press: Chicago, IL, USA, 1969.

19. Robinson, H.H. The San Franciscan Volcanic Field, Arizona; US Government Publishing Office: Washington, DC, USA, 1913.

20. Sharp, R. Multiple Pleistocene Glaciation on San Francisco Mountain, Arizona. J. Geol. 1943, 50, 481-503. [CrossRef]

21. Colton, H. Sunset Crater: The Effect of a Volcanic Eruption on the Ancient Pueblo People. Geogr. Rev. 1932, 22, 582-590. [CrossRef]

22. Colton, H. The Eruption of Sunset Crater as an Eyewitness Might Have Observed It. Mus. Notes 1937, 10, 9-12.

23. Colton, H. San Francisco Peaks. Museum of Northern Arizona. Mus. North. Ariz. Mus. Notes 1930, 3, 2.

24. Colton, H. The Basaltic Cinder Cones and Lava Flows of the San Francisco Mountain Volcanic Field. Bulletin 10; Museum of Northern Arizona: Flagstaff, AZ, USA, 1967.

25. Colton, H. A Possible Hopi Tradition of the Eruption of Sunset Crater. Mus. Notes 1932, 5, 23. 
26. Crossing Worlds. Sacred Peaks Meanings to Northern Arizona Tribes. Available online: https://crossingworlds.com/sacredpeaks-meaning/ (accessed on 7 December 2021).

27. Bennett, M.; Bustos, D.; Pigati, J.; Springer, K.; Urban, T.; Holliday, V.; Reynolds, S.; Budka, M.; Honke, J.; Odess, D. Evidence of Humans in North America during the Last Glacial Maximum. Science 2021, 373, 1528-1531. [CrossRef] [PubMed]

28. Arizona Geologic Survey. San Francisco Volcanic Field. Available online: https://azgs.arizona.edu/photo/san-franciscovolcanic-field-arizona (accessed on 5 December 2021).

29. Hooton, J.; Ort, M.; Elson, M. The Origin of Cinders in Wupatki National Monument, 2001-2012; Desert Archaeology Inc.: Tucson, AZ, USA, 2001

30. Elson, M.; Ort, M.; Anderson, K.; Sheppard, P.; Samples, T.; Heidke, J. In the Shadow of the Volcano: Prehistoric Settlement in the U.S. 89 Project Area. In Sunset Crater Archaeology: The History of a Volcanic Landscape; Elson, M., Ed.; Anthropological Papers; Desert Archaeology Inc.: Tucson, AZ, USA, 2011; pp. 187-212.

31. Elson, M.; Ort, M.; Anderson, K.; Heidke, J. Living with the Volcano: The 11th Century AD Eruption of Sunset Crater. In Under the Shadow: Cultural and Environmental Responses to Volcanic Eruptions; Grattan, J., Torrence, R., Eds.; Left Coast Press: Walnut Creek, CA, USA, 2007; pp. 107-132.

32. Elson, M.; Ort, M.; Anderson, K. Sunset Crater and Little Springs Volcano Eruptions: Disaster Management in the Eleventh Century AD Southwest. In Exploring Cause and Explanation: Historical Ecology, Demography, and Movement in the American Southwest; Herhahn, C.L., Ramenofsky, A., Eds.; University of Colorado Press: Boulder, CO, USA, 2016; pp. 47-72.

33. USGS. Sunset Crater Lava with Impressions of Prehistoric Corn Cobs Recovered from a Site Investigated as Part of the U.S. 89 Project. Available online: https://www.usgs.gov/volcanoes/san-francisco-volcanic-field/sunset-crater (accessed on 29 December 2021).

34. Elson, M.; Ort, M.; Hesse, J.; Duffield, W. Lava, Corn, and Ritual in the Northern Southwest. Am. Antiq. 2002, 67, 119-135. [CrossRef]

35. Arizona Geologic Survey. Wupatki Pueblo Photo. Available online: https://azgs.arizona.edu/photo/sunset-crater-pueblo-ruinswupatki-national-monument (accessed on 5 December 2021).

36. Schley, R. Excavation of the Wupatki Blowhole Site, NA7824. Memorandum, RM-3266-RC, November,1962; The RAND Corporation: Santa Monica, CA, USA, 1962.

37. Evans, M.; Stoffle, R.; Pinel, S. Petroglyph National Monument Rapid Ethnographic Assessment Project; Bureau of Applied Research in Anthropology, University of Arizona: Tucson, AZ, USA, 1992.

38. Van Vlack, K.; Stoffle, R.; Pickering, E.; Brooks, K.; Delfs, J. Unav-Nuquaint: Little Springs Lava Flow Ethnographic Investigation; Bureau of Applied Research in Anthropology, University of Arizona: Tucson, AZ, USA, 2013.

39. Zedeno, M.; Schrag-James, J.; Basaldu, C. Overview and Inventory of Ethnographic Resources for Petrified Forest National Park, El Malpais National Monument and Conservation Area, and El Morro National Monument; Bureau of Applied Research in Anthropology, University of Arizona: Tucson, AZ, USA, 2001.

40. Zedeno, M.; Stoffle, R.; Dewey-Hefley, G.; Shaul, D. Storied Rocks: American Indian Inventory and Interpretation of Rock Art on the Nevada Test Site; University of Arizona: Tucson, AZ, USA, 1998.

41. Lowie, R. The History of Ethnological Theory; University of Michigan Press: Ann Arbor, MI, USA, 1937.

42. American Ethnological Society. The American Ethnologist. Available online: http://americanethnologist.org (accessed on 7 December 2021).

43. Toupal, R.; Stoffle, R. Cultural Affiliation Study of Navajo National Monument, Black Mesa, Arizona and Sunset Crater Volcano National Monument, Walnut Canyon National Monument, Wupatki National Monument, Flagstaff, Arizona; Bureau of Applied Research in Anthropology, University of Arizona: Tucson, AZ, USA, 2001.

44. Toupal, R.; Stoffle, R. Traditional Resource Use of the Flagstaff Area Monuments; Bureau of Applied Research in Anthropology, University of Arizona: Tucson, AZ, USA, 2004.

45. National Park Service. Sunset Crater Volcano National Monument Draft Environmental Impact Assessment; Sunset Crater National Monument: Flagstaff, AZ, USA, 2001.

46. Mercer, J.A. Preliminary Assessment of Hopi Ethnohistory in the Wupatki, Sunset Crater Volcano, and Walnut Canyon National Monument Area near Flagstaff, Arizona; Four Corners Research, Inc.: Tularosa, NM, USA, 1999.

47. Begay, R.; Begay, S. Nihikék' Eh Nahaz': Our Place in This Land; Division of Natural Resources, Navajo Nation: Window Rock, AZ, USA, 2003.

48. Wikipedia Commons. Wupatki Ballcourt Photo. Available online: https://commons.wikimedia.org/wiki/File:Wupatki_ballcourt. jpg (accessed on 7 December 2021).

49. Ferguson, T.; Lomaimvaya, M. Nuvatukya'ovi, Palatsmo, Niqw Wupatki: Hopi History, Culture, and Landscape; Desert Research Institute: Tucson, AZ, USA, 2000.

50. Nequatewa, E. The Truth of a Hopi. Stories Relating to the Origin, Myths, and Clan Histories of the Hopi; Northland Publishing: Flagstaff, AZ, USA, 1936.

51. Wikipedia Commons. Wupatki Blowhole Photo. Available online: https://commons.wikimedia.org/wiki/File:Wupatki_ blowhole.JPG (accessed on 7 December 2021).

52. Petroglyph National Monument. Petroglyph National Monument Visitor Center Photo. Available online: https://s3.amazonaws. com/gs-waymarking-images/b655dd84-57a3-487f-ba15-c2bc34602c4e.JPG (accessed on 7 December 2021). 
53. Stevenson, M. Studies of the Tewa Indians of the Rio Grande Valley. Smithson. Misc. Collect. 1913, 60, 35-41.

54. Parsons, E. The Social Organization of the Tewa of New Mexico; American Anthropological Association Memoirs: Arlington, VA, USA, 1929; Volume 36.

55. Franklin, H. Piedras Marcadas (LA 290) Ceramics: The Pottery of a Classic Period Rio Grande Pueblo, Maxwell Museum Technical Series No. 30; University of New Mexico: Albuquerque, NM, USA, 2017.

56. Van Vlack, K. Dancing with Lava: Indigenous Interactions with an Active Volcano in Arizona. In Anthropological Perspectives on Environmental Communication; Sjölander-Lindqvist, A., Murin, I., Dove, M., Eds.; Palgrave: London, UK, 2022.

57. Billingsley, G. Geologic Summary for Geologic Map of Part of the Uinkaret Volcanic Field, Mohave County, Northwestern Arizona; United States Geological Survey: Washington, DC, USA, 2001.

58. Sapir, E. Southern Paiute, a Shoshonean Language. Proc. Am. Acad. Arts Sci. 1930, 65, 1-296. [CrossRef]

59. Ort, M.; Elson, M.; Anderson, K.; Duffield, W.; Samples, T. Variable Effects of Cinder-Cone Eruptions on Prehistoric Agrarian Human Populations in the American Southwest. J. Volcanol. Geotherm. Res. 2008, 176, 363-376. [CrossRef]

60. Ort, M.; Elson, M.; Anderson, K.; Duffield, W.; Hooton, J.; Champion, D.; Waring, G. Effects of Scoria-Cone Eruptions upon Nearby Human Communities. Geol. Soc. Am. Bull. 2008, 120, 476-486. [CrossRef]

61. Stoffle, R.; Sittler, C.; Albertie, M.; Johnson, C.; Kays, C.; Penry, G. Ethnographic Overview and Assessment for Hovenweep National Monument; University of Arizona: Tucson, AZ, USA, 2019.

62. Noble, D. The Mesa Verde World; School of American Research Press: Santa Fe, NM, USA, 2014.

63. Wilshusen, R.; Varien, M. Seeking the Center Place: Archaeology and Ancient Communities in the Mesa Verde Region; University of Utah Press: Salt Lake City, UT, USA, 2002.

64. Wilshusen, R.; Glowacki, D. An Archaeological History of the Mesa Verde Region. In The Oxford Handbook of Southwest Archaeology; Mills, B., Fowles, S., Eds.; Oxford University Press: New York, NY, USA, 2017; pp. 307-322.

65. Stoffle, R. Living Stone Bridges: Epistemological Divides in Heritage Environmental Communication. In Anthropological Perspectives on Environmental Communication; Sjölander-Lindqvist, A., Murin, I., Dove, M., Eds.; Palgrave: London, UK, 2022.

66. Sjölander-Lindqvist, A.; Murin, I.; Dove, M. Anthropological Perspectives on Environmental Communication; Palgrave: London, UK, 2022.

67. Stoffle, R.; Arnold, R.; Bulletts, A. Talking with Nature: Southern Paiute Epistemology and the Double Hermeneutic with a Living Planet. In Collaborative Heritage Management; Tully, G., Ridges, M., Eds.; Gorgias Press: Piscataway, NJ, USA, 2016 ; pp. 75-100. 